\title{
Geomorphological settings of Polish research areas on Spitsbergen ${ }^{1}$
}

\section{Zbigniew Zwoliński ${ }^{1}$, Jerzy Giżejewski², Andrzej Karczewski ${ }^{1}$, Marek Kasprzak ${ }^{3}$, Krzysztof Roman Lankauf ${ }^{4}$, Piotr Migoń ${ }^{3}$, Kazimierz Pękala ${ }^{5}$, Janina Repelewska-Pękalowa ${ }^{5}$, Grzegorz Rachlewicz ${ }^{1}$, Ireneusz Sobota ${ }^{4}$, Wojciech Stankowski ${ }^{6}$, Piotr Zagórski ${ }^{5}$}

${ }^{1}$ Institute of Geoecology and Geoinformation, Adam Mickiewicz University in Poznań, Poland, zbzw@amu.edu.pl

${ }^{2}$ Institute of Geophysics, Polish Academy of Sciences, Warszawa, Poland

${ }^{3}$ Institute of Geography and Regional Development, University of Wroctaw, Poland

${ }^{4}$ Faculty of Earth Sciences, Nicolaus Copernicus University, Torun, Poland

${ }^{5}$ Faculty of Earth Sciences and Spatial Management, Maria Curie-Skłodowska University, Lublin, Poland

${ }^{6}$ Institute of Geology, Adam Mickiewicz University in Poznań, Poland

\begin{abstract}
Paper described geomorphological characteristics of landform sets which occur on research areas investigated by Polish geomorphologists on Spitsbergen. These area involve four areas along the western coast of Spitsbergen, i.e. vicinities of the Kaffiøyra, the Werenskioldbreen, the Calypsostranda, and the Hornsund, as wel as one area located in the central part of Spitsbergen, i.e. vicinity of Billefjord with special emphasis on surroundings of the Petuniabkukta. Landforms are characterized in different morphogenetic terms, mainly glacial, peryglacial, deundational, slope, fluvial, even eolian factors and processes.
\end{abstract}

Key words: polar landform, polar geomorphology, glacial relief, postgalacial relief, Polish geomorphological research, Spitsbergen

\section{Introduction}

The Svalbard archipelago, one of the most scientifically interesting place in the High Arctic, is located between $74^{\circ}$ and $81^{\circ} \mathrm{N}$ and $10^{\circ}$ and $35^{\circ} \mathrm{E}, \sim 800 \mathrm{~km}$ north of the coast of Norway, and $\sim 1100 \mathrm{~km}$ south of the North Pole. Located in the North Atlantic, the archipelago is bordered from the north by the Arctic circumpolar basin, to the east by the Barents Sea and from the west by the Greenland Sea. The archipelago covers an area of $61,020 \mathrm{~km}^{2}$ (NOS 2009), and consists of numerous islands, the largest of which are: West Spitsbergen (Vest-Spitsbergen), now known as Spitsbergen ${ }^{1}$, North East Land (Nordaustlandet), Edge Island (Edgeoya), Barents Island (Barentsoya) and Charles Land (Prins Karls Forland). Spistbergen, discovered by Dutch whalers in 1596, is the largest island,

\footnotetext{
1 This paper is a synopsis from different chapters of the monograph "Dawne i współczesne geoekosystemy Spitsbergenu: polskie badania geomorfologiczne / Ancient and modern geoecosystems of Spitsbergen: polish geomorphological research" edited by Zbigniew Zwoliński, Andrzej Kostrzewski and Marian Pulina published by the Association of Polish Geomorphologists and Bogucki Wydawnictwo Naukowe in 2013.
}

\footnotetext{
For many years, the name Spitsbergen was applied to the entire archipelago, and the largest island, now known by this name, was called Vest-Spitsbergen.
}

covering an area of $37,673 \mathrm{~km}^{2}$ (NOS 2009). The name means "pointed mountains" in reference to its tall mountain peaks, which rise from the sea. The highest of these, Newtontoppen, located in the northern part of the island, reaches a height of $1,713 \mathrm{~m}$ a.s.l.

Polish research stations which are located along the west coast and in the central part of Spitsbergen, and include (Fig. 1; from south to north):

- the Stanisław Siedlecki Polish Polar Station in Hornsund, operated by the Institute of Geophysics of the Polish Academy of Sciences,

- the Stanisław Baranowski Polar Station, in the foreland of the Werenskioldbreen, operated by the University of Wrocław

- the Calypsobyen Polar Station in Bellsund, operated by Maria Curie-Skłodowska University in Lublin,

- the Kaffiøyra Polar Station in Oscar II Land, operated by Nicolaus Copernicus University in Toruń,

- the Polar Station in Petunia Bay in central Spitsbergen, operated by Adam Mickiewicz University in Poznan. 


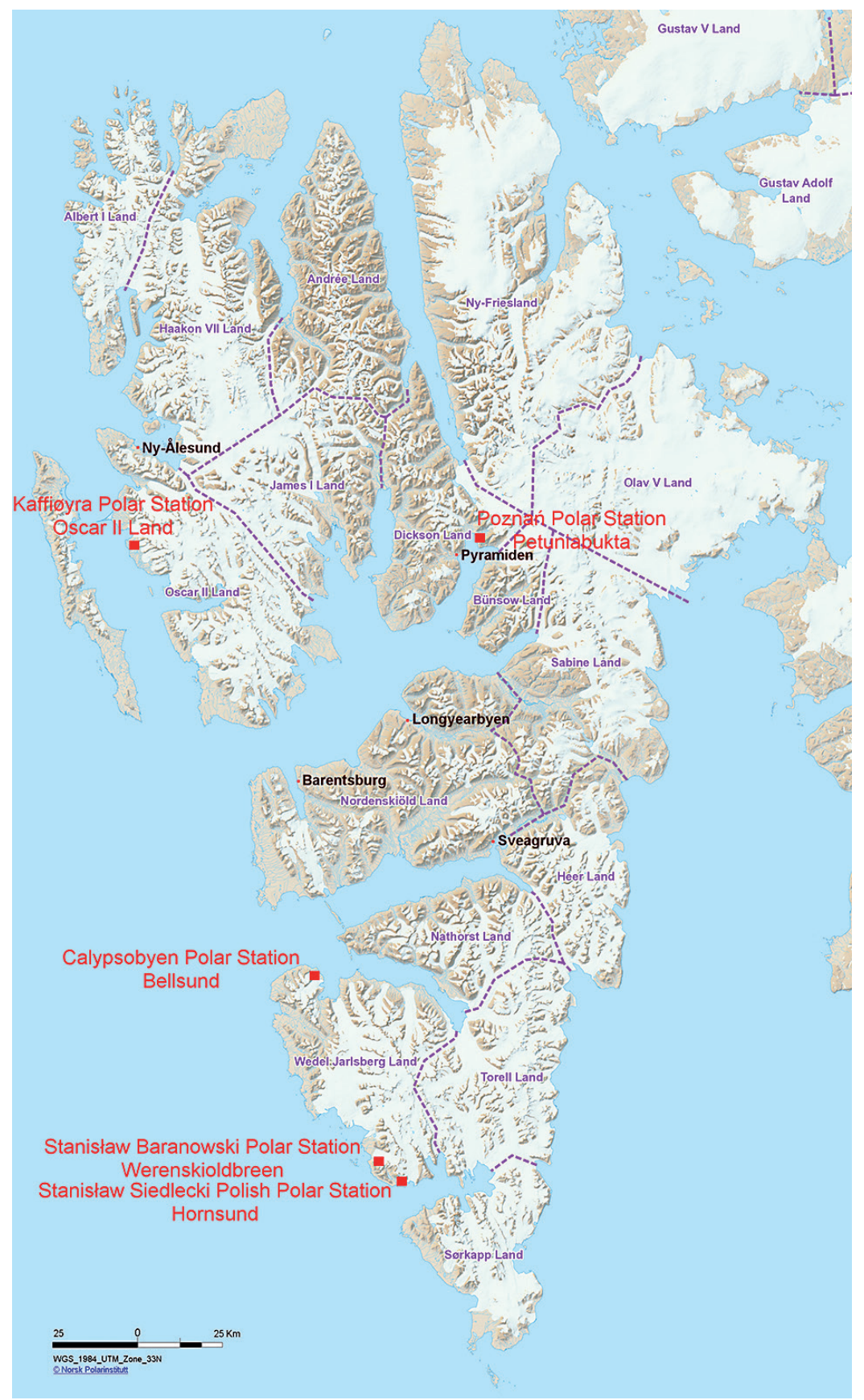

Fig. 1. Location of Polish polar stations on Spitsbergen where are carried out main geomorphological investigations

\section{General characteristics of Spitsbergen's landforms}

The physiographical characteristics of Spitsbergen are determined by two factors, the geological structure of its tectonics and its climate. Spitsbergen is the result of geological formations originating from the Precambrian to the Quaternary. Its primary geological units feature a meridional arrangement. The oldest known formations, Hecla Hoek rocks, are found on the west coast and in the north-eastern part of the island. They are formed mainly of metamorphosed crystalline rock, quartzite, marble and slate. They appear topographically as formidable mountain ranges with sharp ridges and steep slopes.
The central and eastern parts of the island are comprised of rock from the Middle and Upper Paleozoic and Mesozoic eras. They frequently occur horizontally or at a slight incline. Topographically, they form extensive plateaus and mountain outliers, surrounded by vast valleys with steep slopes and extensive talus cones. The overall system of mountain ranges and wide valleys expresses the lineation of the geological structures and closely follows the meridian. The fjords of the far north - Wijderfjorden and Woodfjorden - are also characterised by such a configuration.

The relief of the western part of central and southern Spitsbergen is marked by three fjords with a latitudinal configuration: Isfjorden, Belsund and Hornsund. Spitsber- 
gen's magnificently developed fjords most probably indicate the path of old valley systems, which were reformed by ice streams during subsequent glaciations in the Quaternary Period. The last glacial gave the fjords their final shape, while climatic fluctuations during the Late Glacial and the Holocene are responsible for its current sedimentation and the subaerial and subaqueous sculpting of their linear concave forms (see e.g., Karczewski, Rygielski 1989, Karczewski et al. 1990, Szczuciński, Zajączkowski 2012). Among the primary polyphase-generated forms related to major ice streams are a system of lower-order glaciers, which today form a dendritic system of Spitsbergen-type glaciers.

Currently, the northern part of the island is the most ice covered, and include large ice-covered fjelds known as fonns. In the northern area, these include Lomonosovfonna (Ny-Friesland), Holtedahlfonna (Haakon VII Land), and the largest, covering all of Olav V Land. The central-eastern part of the island, which is less ice covered, features the Nordmannsfonna ice cap (Sabine Land). In the southern part of Spitsbergen, meanwhile, there is the Sørkappfonna ice cap. All the ice caps, but also major valley glaciers, feature individual or chains of nunataks, which have undergone intense weathering processes, generating intense detrital cover.

Most glaciers on the east coast terminate on ice cliffs on the Barents Sea (for example Strongbreen, Inglefieldbreen). However, the glaciers on the west coast terminate at the Greenland Sea, though much less often on cliffs (for example Vestre Torellbreen, Olsokbreen), and sometimes end far from the open sea in fjords (for example Nordenskiöldbreen, Mittag-Lefflerbreen, Paulabreen, Hornbreen). The forelands of glaciers terminating on land feature the terminal moraines, as well as marginal and extra-marginal sandurs of varying degrees of development (e.g., Elveflya, Vimsa, Gåshamnöyra, Hørbyeflya, Törflya).

Climatically conditioned disparities in Spitsbergen's glaciation ( $\sim 60 \%$ of landmass is ice-covered) is manifested in the altitude of the snow line. On the eastern and south-eastern parts of the island, it occurs at ca. $200 \mathrm{~m}$ a.s.l., and in the central and western parts as high as ca. $800 \mathrm{~m}$ a.s.l. In recent decades, a consistent and often rapid ablation of glaciers has been observed. This process has been ongoing since the latter half of the 19th century, i.e., since the end of the Little Ice Age. The range of glaciers from that time is clearly indicated by the well-developed forms of the marginal zones marking the extent of their expansion (e.g., Hørbyebreen, Ragnarbreen, Scottbreen, Waldemarbreen). It is worth mentioning that at the beginning of the early Middle Ages the level of glaciation on Spitsbergen, especially in the South, was much smaller than today.

It worth emphasizing that the presence on Spitsbergen of several glacier-free large valleys. These are found mainly in the central and southern part of the island. They include Sassendalen, Adventdalen, Reindalen, Colesdalen, Dickdalen and Dunderdalen.
The coastline of Spitsbergen, especially on the western coast, is characterized by a series of well-defined marine terraces. Abrasion shelves, often covered with pebbles reach up to ca. $4 \mathrm{~km}$ in width and rise to at least 100-220 m. On low terraces, even those $10 \mathrm{~m}$ above the present sea level, can be find whale bone fragments and drift wood. At intervals ranging from 100 to $>300 \mathrm{~m}$ there are well-developed abrasion shelves with scattered pebbles. The very complicated fate of Quaternary phenomena in Spitsbergen is evidenced by the following conditions. The highest marine boulder and fragments of weathered marine-type pebbles were found in the upper reaches of Hohenloefjelet (Stankowski 1983). These well developed landforms associated with the actions of the sea provide a good illustration of the complex glacio-isotatic and eustatic processes that occurred on Spitsbergen during the Pleistocene. An eloquent expression of this can also bee seen in data from the region between Billefjorden and Austfjorden (cf. Karczewski, Rygielski 1989, Stankowski 1989), where the presence of fragments of marine pebbles has been reported in the supraglacial debris cover in the marginal sections of the Cambridgebreen (Stankowski 1989). One can also encounter tidal pebbles inside Spitsbergen's fjords (e.g., Petuniabukta or Nottinghambukta), and skerries in the littoral zone of the rocky coast.

The relief of the terrain on the Svalbard archipelago today is the product of the varied geological structure on which multiple glaciations left their mark, including the last one in the Pleistocene, and of isostatic movements associated with the archipelago's subsequent deglaciation.

\section{Landforms in the vicinity of the Hornsund $\operatorname{area}^{2}$}

The morphology of the Hornsund region (Fig. 2), understood to mean the area enclosed by the regional water and ice drainage running down into the fjord, whose NW boundary is the crest separating the Gangpasset and Bratteg valleys, including the northwestern part of Sørkappland up to the Olsokbreen in the south. It includes two main types of landscape: nearshore plains, and an area with a mountain (the mountains on NW Sorkapp) and high-mountain morphology (e.g. the Hornsundtind massif, the Sofiekammen range). This last region is a glaciated area and occupies the largest territory.

The nearshore plains take up about $20 \%$ of the region's area. They form a belt of variable width, ranging from a few dozen meters to several kilometers, between the bases of the shore mountain slopes and the fjord's shoreline. Within this belt lie a number of terraces rising stepwise from the shoreline and sloping gently toward the sea (fjord). Their base includes abrasion surfaces with monadnocks of more resistant rock, and they are built of clastic, most often gravelly marine sediments. The pre-

\footnotetext{
There is a vicinity of the Stanisław Siedlecki Polish Polar Station.
} 


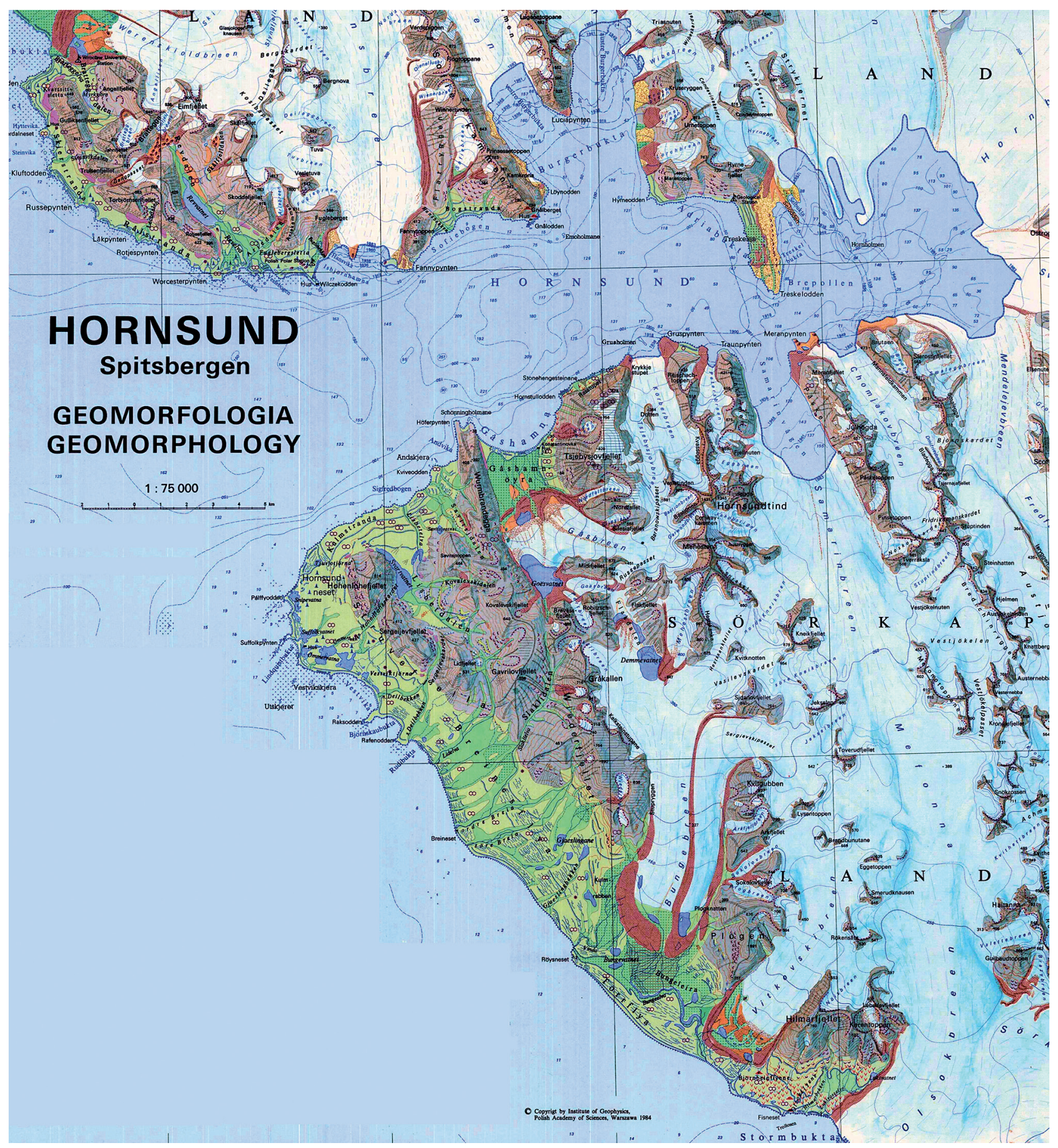

Fig. 2. Fragment of geomorphological map edited by Karczewski (1984)

sence of marine terraces at substantial heights above the present-day sea level testifies to the isostatic uplift of Spitsbergen. The terrace system on the fjord's northern side includes 15 raised marine terraces of the following heights: $230-220 \mathrm{~m}, 205-200 \mathrm{~m}, 190-180 \mathrm{~m}, 115-100 \mathrm{~m}$, 95-80 m, 75-70 m, 65-60 m, 46-45 m, 46-40 m, 35-32 $\mathrm{m}, 25-22 \mathrm{~m}, 18-16 \mathrm{~m}, 12-8 \mathrm{~m}, 6-4.5 \mathrm{~m}$ and $2 \mathrm{~m}$ a.s.1. The levels are unevenly spaced and differ in the details of their genesis (Karczewski 2004). In the neighbourhood of the Hornsund Station, the highest terrace levels are found at $230 \mathrm{~m}$ a.s.l. in the small side branches of the Rev Valley.
Bogstranda, which lies between Fannytoppen and Sofiekammen, forms an isolated section of nearshore plain with terraces. Well developed terrace systems are also found on the Treskelen Peninsula and in the non-glaciated part of Hyrnefiellet.

On the south side of the fjord, raised marine terraces are located at the foot of Rasstupet (Lasurblåstranda plain), in the valleys of Gås and Lisbet, in Kulmstranda, at the base of the northern slopes of Hohenlohefiellet, and on the Breinsflya and Tørrflya plains. Seventeen distinct terrace levels are observed in this area, of the fol- 
lowing heights: 4-3 m, 8-6 m, 18-10 m, 28-20 m, 38-30 $\mathrm{m}, 54-42 \mathrm{~m}, 75-67 \mathrm{~m}, 100-80 \mathrm{~m}, 110-100 \mathrm{~m}, 126-120$ m, 130 m, 160 m, 190-180 m, 200 m, 215 m, 240-230 m and 270-260 m. Remnants of abrasion are found on the slopes of Hohenlohefiellet, at heights of $440 \mathrm{~m}, 380-370$ m, 330 m (Stankowski 1981), though not all authors of studies on the region agree on these figures (Karczewski 2004). The terrace systems on the southern and northern side of the Hornsund fjord differ in the number of terraces, their relative height, and elevation above sea level, which gives reason to believe that the rate of uplift of the two regions was different. A further consequence of this view seems to be that the Hornsund fjord has tectonic origins. Similar conclusions can be drawn from studies of the tectonic micro and meso structures (Bednarek et al. 1993). The systems of raised marine terraces provide very important data for re-creating the glacial and postglacial history of Spitsbergen.

One characteristic element of the morphology of contemporarily unglaciated areas are extensive bar formations at the base of the slopes, composed of unsorted and rough local material from the slopes and rock walls above them. These formations can be up to almost two kilometers long, up to several hundred meters wide and up to $100 \mathrm{~m}$ high. Near the Polish Polar Station, the largest formations of this kind are found at the foot of Rotjesfiellet on the south side, below the slopes forming the western boundary of the Rev Valley, and at the foot of Fugleberget's southern slope. The genesis of these formations is diverse, with most considered to be nival moraines (Szczęsny 2004).

The greatest variety of morphological forms is represented in the marginal zones of glaciers terminating on land. Near the Polish Polar Station, these include a number of small valley glaciers: Gangpasset, which splits at a pass of the same name to form two marginal zones - one in Rev Valley and one in the Gangpasset valley; the Ariebreen in a side valley of the same name, the Sofiebreen, and the lateral moraine zone of the Hansbreen. The Hansbreen front flows into the fjord between the Baranowski and Oceanographer peninsulas, and studies of its underwater marginal zone are in progress.

The glaciers of Sørkappland - the Gåsbreen, Bungebreen and Vitkovskibreen - have extensive marginal zones. The Gåsbreen is the only glacier flowing into the Hornsund from the south and ending on land. The main ice-cored frontal moraine zone stretches across the valley from the slopes of Tsjebysjovfiellet to the slopes of Wurmbrandegga. Lateral moraines run along the base of the slopes, the moraines on the valley's eastern side being much more developed and reaching heights of about 60 $\mathrm{m}$. The lateral moraines below Wurmbrandegga are residual, built of material supplied by small lateral glaciers.

A lake known as Gåsvatnet existed for some years about $1 \mathrm{~km}$ above the frontal moraine beneath the slopes of Wurmbrandegga. Described in 1980, it ultimately disappeared at the beginning of this century. It was an ice dammed lake formed at the junction of several unglaciated minor valleys and a valley of small hanging side glaciers. The dam was formed by the ice of the main part of the Gåsbreen. Within the dam there was a system of drainage channels which froze in winter and in summer enabled the water of the lake to flow onto the glacier's forefield, causing sudden flooding of the Icelandic jokullhlaup type on the inner sandur. The floods were irregular, and did not occur every summer. Today, the glacier front, which slopes gently and is covered with a thick layer of coarse clastic ablation moraine, has receded so far that the depression of the former lake is open to the north. The area between the glacier front and the end moraine lies largely on a base of dead ice that is covered with coarse clastic lodgement moraine or sandur fans. The water flowing from the glacier forms a complicated system of streams that come together in the central part of the ice-cored moraine and flow down the sole gorge into the extensive Gåshamnøyra plain, where they form a vast system of braided streams. These streams come together again in the north-eastern part of the plain and flow down a single outlet into the bay. In its middle part, Gåshamnaøyra is a ground moraine. Most of it is composed of vast and flat sandur fans. These reach the Gåshamna shoreline, forming the Hornsund's longest section of accumulation shore zone.

The Bungebreen flows down from the Plogen massif to the western coast of Sørkappland. There is a system of seven raised marine terraces adjacent to the glacier, from the lowest at a height of 8-6 $\mathrm{m}$ a.s.l. to the highest at 130-100 m. An ice-cored frontal moraine lies about $2 \mathrm{~km}$ from the shoreline. Proglacial waters cut across it in two gorges, forming outer sandur surfaces in the forefield. Between the glacier front and the frontal moraine is a medial moraine with extensive inner sandur fans and marginal lakes on both sides (Karczewski 2004, Kłysz, Lindner 1980).

South of the Bungebreen, between the mountain massifs of Plogen and Hilmarfiellet, lies the Vitkovskibreen. A study of its forefield zone has been presented by Andrzejewski and Stankowski (1981). Lateral and frontal ice-cored moraines lie beyond the boundary of the massifs, and lead into a complex of raised marine terraces: Bjørnbeinflya and Tørrflya. Unlike all the terraces mentioned previously, these are built from fine-grained clastic sediments. The lateral moraine ridges and the frontal moraine are built from coarse-grained clastic sediments. They are separated by two gorges formed by water flowing from the glacier; the northern gorge carries the lateral outflow and the outflow from the central part of the glacier front, whereas the southern outflow is exclusively lateral. The area between the glacier front and the icecored moraine is occupied by a ground moraine with minor elevations of the frontal moraine testifying to the glacier's multiple-stage recession. The depressions contain a number of marginal lakes connected by sandur outflows. Beyond the ice-cored moraine, proglacial water outflows form a number of streams cutting into the system of raised marine terraces. 
All of the areas around the Hornsund not covered with glaciers where periglacial processes are highly active. Frost weathering occurs on the nunataks of the glaciated part, forming waste cover in the parts of slopes with a smaller gradient and scree fans at the base of rock walls and couloir outlets. The weathered material from the rock walls falls onto the snow cover, thus initiating nival transport and the formation of nival moraines at the bottom of the slopes. Gravitational transport is assisted by solifluction processes, including debris flow on the fan surfaces. Gullies on the fan surfaces are a feature typically related to debris flow.

The flat surfaces of raised marine terraces and the peripheral parts of scree fans are area of structure ground formation. Debris festoons form on gently sloping surfaces (e.g. the eastern shore of Revvatnet), polygonal structures and cryogenic soils - on level surfaces (the Środoń Garden at the mouth of Rev Valley).

The flat surfaces of the terraces are covered with tundra vegetation. Locally, even over quite large areas, the tundra's development has led to the formation of areas of peat up to a few dozen centimetres thick. In the autumn freezing period, small hydrolaccolith-type formations are found on these surfaces. Large, multi-year pingo-type formations are rare, while single formations have been observed west of the Rev Valley's mouth and in the region of Hytteviki (Karczewski et al. 1984).

There is permafrost throughout the region described here. Its surface thaws in the summer seasons to a depth of no more than $2 \mathrm{~m}$, forming an active layer in which various processes occur, including sediment segregation. Locally, thermal karst water can burst through the permafrost surface. Such outflows have been reported in the limestone massifs of Gnållberget and Rautfiellet (Pulina 2004). Reaching the shore of the Hornsund fjord from the north (Sofiekammen) and from the south (Tsjebysjovfjellet) are massifs largely built from calcareous rocks, chiefly Old Paleozoic marble. In higher parts, there are traces of surface karst formations - incipient corrosion forms, distinctive washed-away crevices, and rock chimneys typical of karst-forming rocks. The narrow shore belt stretching along the base of these massifs displays visible features of karst processes developing in the littoral zone. The shore here comprises two raised marine terraces: a lower one at 1-2 $\mathrm{m}$ and a higher one at 4-5 $\mathrm{m}$. The higher terrace is bounded by a high limestone cliff with numerous niches and the mouths of small caves. The largest of these is closed with an ice plug a few dozen meters from the mouth. Above the terraces there are monadnocks in the shape of spires and towers. At the base of the edge restricting the lower terrace below Gnalllberget, there is a large karst spring (Orvin Spring) active year-round, with a temperature of $13^{\circ} \mathrm{C}$, and with capacity of a few dozen litres per second. The spring provides drainage for the deep karst flow of the Sofiekammen massif occurring beneath the permafrost zone. There is also an area of springs on the eastern part of the coast, at the base of the Tsjeby- sjovfiellet wall. Undersea outflow has also been observed here. These springs are not thermal (Pulina 2004).

\section{Landforms in the vicinity of the Werenskioldbreen area $^{3}$}

Three major types of relief may be identified in the vicinity of the Werenskioldbreen (Fig. 3):

- a bedrock-cut coastal platform 1-4 km wide with a system of raised marine terraces and relict cliff lines,

- a mountainous terrain further inland with sharply pointed crests, a widespread superficial debris mantle, and valleys partially covered with glaciers and rock glaciers, and

- an extensive foreland zone of the Werenskioldbreen, whose morphology is dominated by glacial and fluvioglacial landforms, currently modified by melt-out processes.

The morphology of the coastal zone is dominated by a wide platform - strandflat, at an elevation of 4-25 $\mathrm{m}$ a.s.l. Inland, it terminates against a distinct concave slope break, above which the Trulsenfjellet, Gullichsenfjellet and Jens Erikfjellet mountain groups rise. Within the strandflat a well developed, stepped system of raised marine terraces exists which are genetically related to the relatively fast isostatic uplift of south Spitsbergen during the Late Glacial/Holocene times (Jahn 1959, Karczewski et al. 1981a). An 8-12 m terrace is most extensive, while isolated remnants of a higher, 16-18 m terrace locally protrude above its level. On the coastal side, the terrace level is truncated by an active cliff a few meters high, or a discontinuous 4-6 m terrace occurs. The most complete sequence of raised marine features are found on the Kvartsittletta flat, just south of the Wrocław Polar Station. As many as six terrace levels have been mapped: 4-6, $8-12,16-18,22-25 \mathrm{~m}$, as well as remnants of 32-35 and $40-46 \mathrm{~m}$ heights. The results of dating driftwood and marine animal bones indicate that the 4-6 $\mathrm{m}$ terrace developed in the period 4.5-7.5 ka BP, while the 8-12 m terrace likely formed between 7 and 14 ka BP. The higher terraces are older, but their precise age remains undetermined (Salvigsen, Elgersma 1993).

In the immediate vicinity of the Wrocław Polar Station well rounded marine pebbles can be found on the rock step at the outlet of the Brattegg Valley at 60-80 m a.s.1. Marine pebbles at the outlet of the hanging Steinvik Valley occur at an even higher altitude, ca. $200 \mathrm{~m}$ a.s.1. (Jahn 1959, Chmal 1987). For example, they occur beneath the mantle of slope solifluction deposits at $205 \mathrm{~m}$ a.s.l. (Kasprzak 2012a). Karczewski et al. (1981a) and Lindner et al. (1991) claimed that the most elevated terrace would be present in the inner parts of Brattegg and Steinvik Valleys, at 220-230 $\mathrm{m}$ a.s.1., but no conclusive evidence was

\footnotetext{
There is a vicinity of the University of Wroclaw's Stanisław Baranowski Research Station.
} 


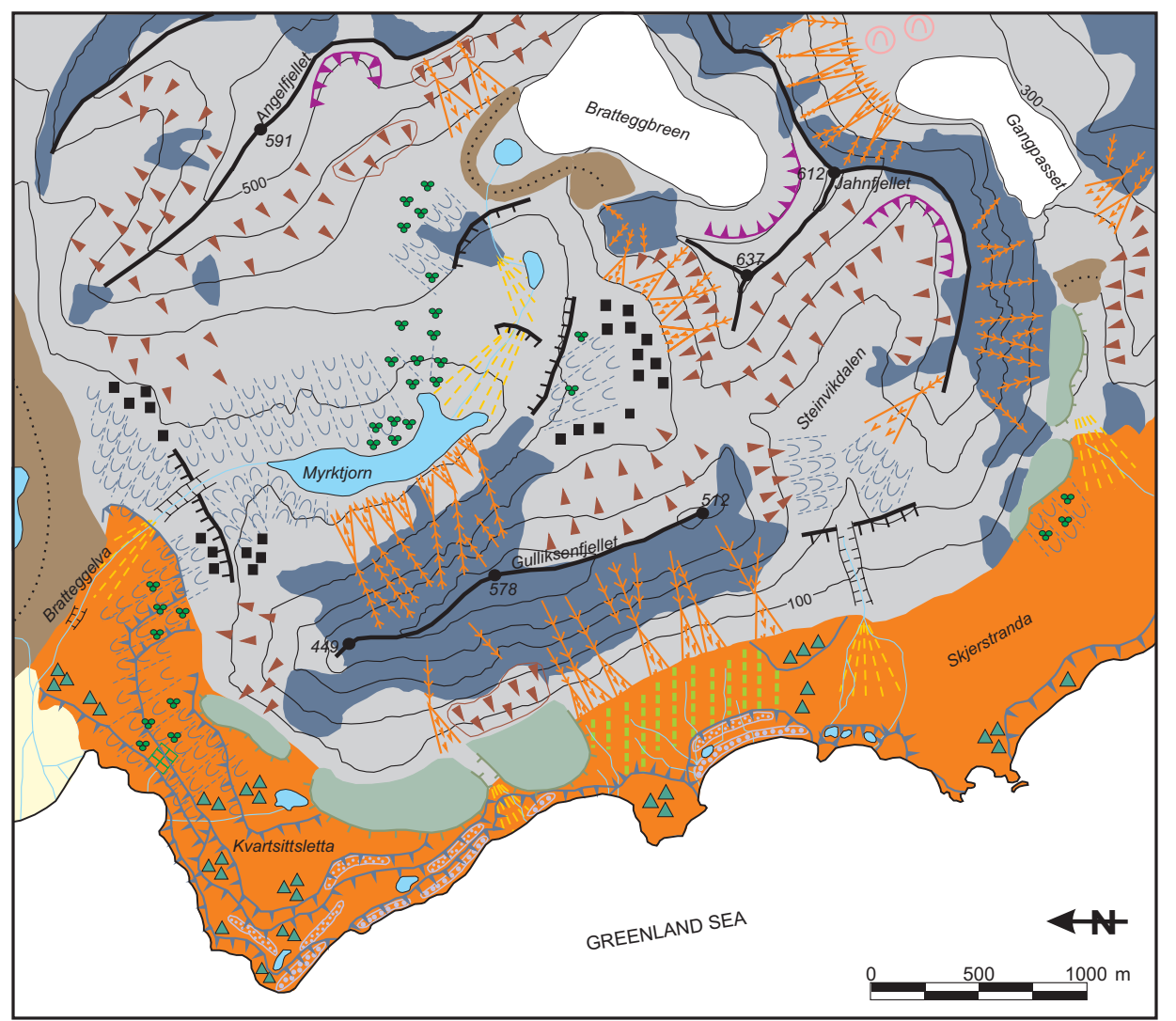

1.

2

3.

4.

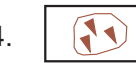

5 .

6

7.

8.

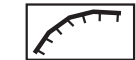

9.

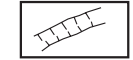

10.

11.
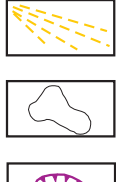

12.

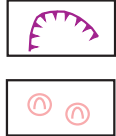

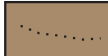

15

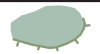

16.

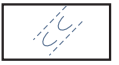

17.

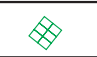

18.

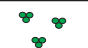

19.

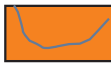

20.

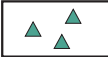

21.
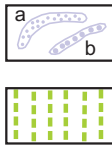

23

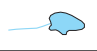

24.

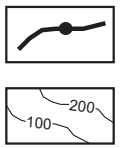

Fig. 3. Geomorphological map of the vicinity of the Baranowski Research Station, outside the glacier basin of Werenskioldbreen, northwest coast of Hornsund (by A. Latocha, K. Parzóch, based on maps by Karczewski (1984) and Chmal et al. (1988), supplemented by field mapping in 2005)

Denudational landforms: 1. rock slopes, 2. debris mantled slopes, 3. Talus, 4. boulder blankets, compact, 5. boulder blankets, dispersed, 6. ravines and chutes, 7. scree cones, 8. rock steps; Fluvial landforms: 9. erosional incisions, 10. alluvial fans; Glacial landforms: 11. glaciers and perennial snow patches, 12. edges of glacial cirques, 13. roche moutonnées, 14. moraine ridges, 15. rock glaciers; Periglacial landforms: 16. solifluction stripes and lobes, 17. frost crack networks, 18. patterned ground; Littoral landforms: 19. raised marine terraces within strandflat, 20. sea stacks, 21. storm ridges: a. older, b. younger; Biogenic landforms: 22. organogenic cover deposits; Others: 23. streams and lakes, 24. selected ridges and peaks,25. contour lines

provided. Alternatively, these leveled surfaces may be of glacial erosional origin.

The shoreline to the south of the Wrocław Polar Station is dominated by a low rock-cut cliff with a variable width abrasion platform extending seaward in front of it. Gravelly and pebbly beaches with storm bars occur subordinately, mainly in embayments (Steinvik, Hyttevika), but also locally at the foot of the cliff. In this way beaches play a protective role against direct wave impact, at least during part of the year. The coastal rock's morphology shows structural control, particularly between the bays of Hyttevika and Nottinghambukta. The coast truncates rocks belonging to the Gullichsenfjellet Formation, composed of folded quartzites and mica schists (Manecki et al. 1993). Quartzites are apparently much more resistant and build narrow bedrock ridges and outliers up to $8 \mathrm{~m}$ high, separated by $2-5 \mathrm{~m}$ wide troughs excavated in schists. A similar relationship between the rocks and relief may be observed within the contemporary wave-cut platform.

In contrast to the predominantly bedrock-cut littoral morphology found to the south of the mouth of the river draining the Werenskioldbreen, i.e. Werenskioldelva, extensive flat outwash plains typify the area north of the river. Deposition has been accomplished by three rivers: the Kvisla, which used to drain the northern part of the Werenskioldbreen basin, the Vimsa, draining the Nannbreen, and the Iskantelva, fed by the Torellbreen. Currently, it is chiefly the Werenskioldelva that actively shapes the coastline through massive deltaic deposition in the bay of Nottinghambukta (Kowalska, Sroka 2008). Ongoing siltation of the bay has effectively cut the Polar Station off from goods supplied by sea. An abrasion platform reappears only at the extension of the Jens Erikfjellet ridge but is as much as $4 \mathrm{~km}$ wide. On the surface of the most extensive outwash plain, Elveflya, 2-4 $\mathrm{m}$ high storm ridges may be observed. They separate small coastal lakes from the open sea.

The morphology of the raised marine terraces is moulded by cryogenic processes related to the presence and seasonal thawing of permafrost, and the origin and decay of various forms of ground ice (Brázdil et al. 1988). Superficial evidence of these processes includes various ground patterns, orthogonal networks of frost cracks in storm ridges, and spotted tundra surfaces with 'islands' of clayey material surrounded by larger clasts and debris. Among the characteristic cryogenic landforms are low, peat-covered hummocks with ice cores known as hydrolaccoliths (Klementowski, Konečný 1988). They attain dimensions of up to $35 \mathrm{~m}$ in length, $15 \mathrm{~m}$ in width and 1.5 $\mathrm{m}$ in height. The peat layer's thickness above the ice core 
may reach $35 \mathrm{~cm}$. Hydrolaccoliths are subject to a constant process of growth and destruction. Subsurface tunnel (pipe) flow in peat plays an important role in the origin of hummocks. Progressive freezing of water in conduits leads to localized arching of the tundra surface, whereas ice completely filling the tunnels marks the end of the growth phase. This is followed by the degradation phase which is initiated by the emergence of cracks along the hummock's axis . Fragmentation of the peat blanket diminishes its protective role and allows rainwater to penetrate inside the hummocks thus opening room for thermal erosion. Hydrolaccoliths form relatively quickly, in less than a decade, while their decay lasts for 20 years or so.

Mountain slopes in the vicinity of the Wrocław Polar Station are highly diverse morphologically which is indicative of both lithological and structural controls as well as the peculiarities of periglacial morphogenetic environments. There are three main slope types:

- rock slopes,

- talus (scree) slopes, and

- debris-mantled slopes with boulders and finer debris.

They differ from one another in terms of cover materials, gradient, and the nature of dominant morphogenetic processes (Jahn 1961).

Rock slopes are ubiquitous in the Gullisenfjellet and Jens Erikfjellet mountain massifs and they also surround the amphitheatre of the Brattegg valley head. They are intricately sculpted into alternating ribs and ravines with the latter being the main pathways for downslope transport of debris. The presence of rock slopes is considerably influenced by lithology and rock strength. They are common in hard quartzites, but disappear in mica schists and amphibolites. In the latter, slope inclination decreases and the topographic surface is made of cover materials: in situ weathering products and mobile debris layer. Rock slopes give way to scree slopes typically built of coalescing cones. The largest landforms of this type occur in the footslope zones of Mt Gullichsenfjellet and Mt Jens Erikfjellet. Cones are shaped by two distinctive types of processes. The first is particle and rock falls which leads to debris accumulation at the mouth of ravines. In the second, debris flows occur episodically but leave distinct geomorphic evidence in the form of linear furrows dissecting cone surfaces with parallel levees (Owczarek 2010).

Many slopes have a tripartite structure. Below the rock walls and aprons of coalescing scree cones there extends a less inclined slope segment $\left(9-10^{\circ}\right)$, where solifluction is the main means of debris transfer downslope (Jahn 1967, Kasprzak 2012b). Solifluction is also a landforming process, responsible for the origin of the particular microrelief of debris-mantled hillslopes. Its effects are ubiquitous on the lower slopes of Mt Angelfjellet and include widespread lobes, terracettes and staircases due to layered solifluction.

Rock glaciers, i.e. accumulations of boulders and debris cemented by ice and capable of slow movement, are unique geomorphic elements of periglacial hillslopes. They are quite abundant in the vicinity of the Wrocław
Polar Station. The largest complex is located along the north-western footslope of Mt Gullichsenfjellet where the rampart attached to the slope extends over $2 \mathrm{~km}$. The rock glacier bulge is up to $400 \mathrm{~m}$ wide while the steep frontal parts reach a height of $20 \mathrm{~m}$. The topography of the rock glacier complex is very diverse with numerous melt-out hollows and chaotically distributed quartzite blocks up to 3-4 $\mathrm{m}$ long. The landform is a talus-derived rock glacier, formed through ice cementation of slope material moved to the footslope zone. It is worth noting that prior to the recognition of rock glaciers, these landforms used to be interpreted in various ways. They were explained as lateral moraines of 'normal' glaciers (Jahn 1959), footslope nival moraines (Karczewski et al. 1981b) and scree moraines (Birkenmajer 1982). Electrical resistivity studies carried out in 2012 yielded results compatible with the presence of ice inside the ramparts.

The rock glacier in the upper part of the Werner Valley, north of the Werenskioldbreen, is of different origin. It appears as a sinuous, wide, stony tongue in the central part of the valley. It has evolved from a glacier tongue fed by a small cirque below the summit of Mt Tonefjellet, hence it is classified as a glacier-derived rock glacier. It likely contained a considerable amount of debris during the glacier phase of evolution, whereas during deglaciation the proportion of debris to ice significantly increased, so that relict glacier ice began to play the role of cement.

An intriguing geomorphic feature of as yet unknown origin, but most likely produced by mass movements, is the huge pile of debris at the foot of the west-facing slope of Mt Jens Erikfjellet. It used to be interpreted as a nival moraine rampart (Karczewski 2004) or a rock glacier (Jania et al. 2004), but it more resembles a colluvial deposit from a deep-seated rock slide of considerable size. It has the shape of a tongue $500 \mathrm{~m}$ long and 35-40 m high, built of chaotically arranged and heavily weathered boulders. Similarly enigmatic is the origin of a complex of debris lobes mantling the raised marine terrace at the mouth of the Steinvik valley close to the Hyttevika Bay. Jahn (1967) suggested that the lobes may have originated from a slush avalanche.

Unglaciated terrain in the vicinity of the Stanisław Baranowski Polar Station is currently enlarging due to the ongoing retreat of the Werenskioldbreen. Except for the abrasion platform and the outwash fan complex of Elveflya described above, the glacier foreland is an assemblage of glacial and glacifluvial landforms bordered by a wide rampart of terminal moraine.

Easy access and continuous recording of geomorphic change, carried out essentially on a yearly basis, allowed for repeated mapping of the proglacial terrain in front of the Werenskioldbreen. Geomorphological maps were published by Szupryczyński (1963), Chmal (1984) and Chmal et al. (1988). Surface changes can also be traced on aerial photographs taken in different years and on topographic maps, while the situation presented on a contoured map prepared in 1957-59 using terrestrial photogrammetry (Lipert 1961) serves as a basis for comparison. 
The proglacial landscape is dominated by the terminal moraine of the Werenskioldbreen. It assumes the form of an asymmetric rampart that is steeper on the distal (western) side and bordered by fluvial incisions on the north and south. The length of the rampart, as measured along the most elevated points between the two river gorges, is $3.1 \mathrm{~km}$. The elevation reaches $88-90 \mathrm{~m}$ a.s.l. in the northern part of the moraine, while the relative height exceeds $60 \mathrm{~m}$. Numerous melt-out depressions dot the surface of the moraine.

The lateral moraines of the Werenskioldbreen vary in shape. The one on the northern side is attached to the footslopes of Mt Jens Erikfjellet and shows a more complex morphology. The southern moraine appears west of Mt Angelfjellet in the form of an irregular rampart with a height of $15-30 \mathrm{~m}$ and an initial width of $300 \mathrm{~m}$ which tapers off towards the terminal moraine. In common with the frontal moraine, many water-filled melt-out hollows, some more than $10 \mathrm{~m}$ deep, occur along its crest. The Werenskioldbreen hosts a middle moraine, too. It begins at the Glasiologknausen nunatak (702 m a.s.1.) and continues towards the glacier toe. The moraine is cut by a crack which formed in response to differences in the masses and rates of movement of the two ice streams. All moraines of the Werenskioldbreen contain glacier ice inside. Electrical resistivity studies carried out in 2012 indicate the presence of frozen bedrock beneath the buried glacier ice.

The area between the contemporary margin of the Werenskioldbreen and its frontal moraine is ca. $2 \mathrm{~km}$ wide (as of 2012). Low recessional moraines measuring a few metres high occur immediately beyond the glacier toe. However, most of this terrain is occupied by ground moraine, locally fluted in front of the northern glacier lobe. To the west, the moraine flattens out. The surface of the moraine is covered by a boulder lag composed of all rock types from the alimentation area or by fine-grained outwash deposits of proglacial rivers. The ground moraine lies either on bedrock or on older glacial (glacifluvial?) deposits. Rock outcrops, particularly on the slopes of Mt Angelfjellet, show the imprint of glacial polishing.

A distinct type of moraine morphology occurs beyond the frontal moraine, at its foot. These are singular elongated ridges, up to $4 \mathrm{~m}$ high. In the past they were either overlooked or erroneously interpreted as eskers (Szupryczyński 1963). Recent geophysical studies and purposefully made outcrops show unequivocally that these ridges are push moraines, built of plastically deformed sedimentary layers.

\section{Landforms in the vicinity of the Calypsostranda ${ }^{4}$}

The north west area of Wedel Jarlsberg Land situated between the Dunder Valley, southern Bellsund and the

\footnotetext{
4 There is a vicinity of the Calypsobyen Polar Station in Bellsund (Maria Curie-Skłodowska University in Lublin).
}

Recherche Fjord is a mountainous area divided by contemporarily glaciated valleys. The peak area is situated at $650-850 \mathrm{~m}$ a.s.1. and constitutes $3 \%$ of the area. It is formed by narrow structural ridges whose widths increase the greater the distance from the central part of the area. The main component of the relief is flat and 400-600 m high, occupying $30 \%$ of the area. The average height of the NW area of Wedel Jarlsberg Land is $240 \mathrm{~m}$ a.s.1.

The varying resistance of rocks and complicated arrangement of foundation structures has influenced the development of the relief of structural features: preparation of ridges and fault scarps, formation of depressions resembling the course of soft rocks and development of erosion cuts (canyons) in zones with tectonic cracking (Pękala 1987, Pękala, Repelewska-Pękalowa 1988, Pękala, Reder 1989).

Within the valleys and ridges there were three structural-denudation levels : 400-500m a.s.1., 200-300 m a.s.1., 100-150 m a.s.l. Their character is that of level, broad intervalley ridges, flatness in the upper parts of valleys as well as steps on the slopes of mountain ridges. The upper parts of the firn fields are covered with contemporary glaciers. The lower level (100-150 m a.s.1.) is situated within lower parts of valleys and bears traces of remodeling by Pleistocene glaciers and Holocene periglacial processes.

Besides the components of structural-denudation relief, forms shaped by glaciers, marine waves and fluvial processes occur. These are glacier valleys, basins of contemporary glaciers with accumulation relief in the marginal zone (frontal ice - moraine bars, ground moraines, eskers and kames as well as inner and outer outwashes, raised marine terraces and erosion cuts (Fig. 4) (Nitychoruk et al. 1989, Szczęsny et.al. 1989, Reder, Zagórski $2007 \mathrm{a}, \mathrm{b})$.

Rise marine terraces are the direct effect of sea level changes connected to glacial-interglacial cycles and glacio-isostasy. In the area of southern Bellsund, called Calypsostranda, they form systems of steps, where characteristic storm berms indicating the former shoreline and dead cliffs and paleo-skerries related to marine abrasion occur. Seven types of terrace within a range from 2 to 85 meters above sea level were specified (Harasimiuk, Jezierski 1988, 1991, Zagórski 2002, Zagórski et al. 2006). The highest terrace at $70-85 \mathrm{~m}$ (VII) is in the form of a slightly inclined abrasion platform. It is located close to upper denudation levels with distinct traces of glacial reshaping in the area of Bohlinryggen Ridge, while in the forefield of the Scottbreen it was partly built up by the ice-moraine ridge. The abrasion character is also observed in terrace VI at 50-65 m high. The age of those terraces is difficult to determine because of the lack or residual occurrence of accumulation deposits. Their surfaces also show traces of distinct glacial reshaping, so it is supposed that they are of pre-Weichselian age. Marine terraces (V-I), located below, have accumulation features. This indicates multi-stage development of those surfaces in the late Pleistocene age, when periods of sea transgression occurred interchangeably with the development of glaciers. A terrace of 40-50 


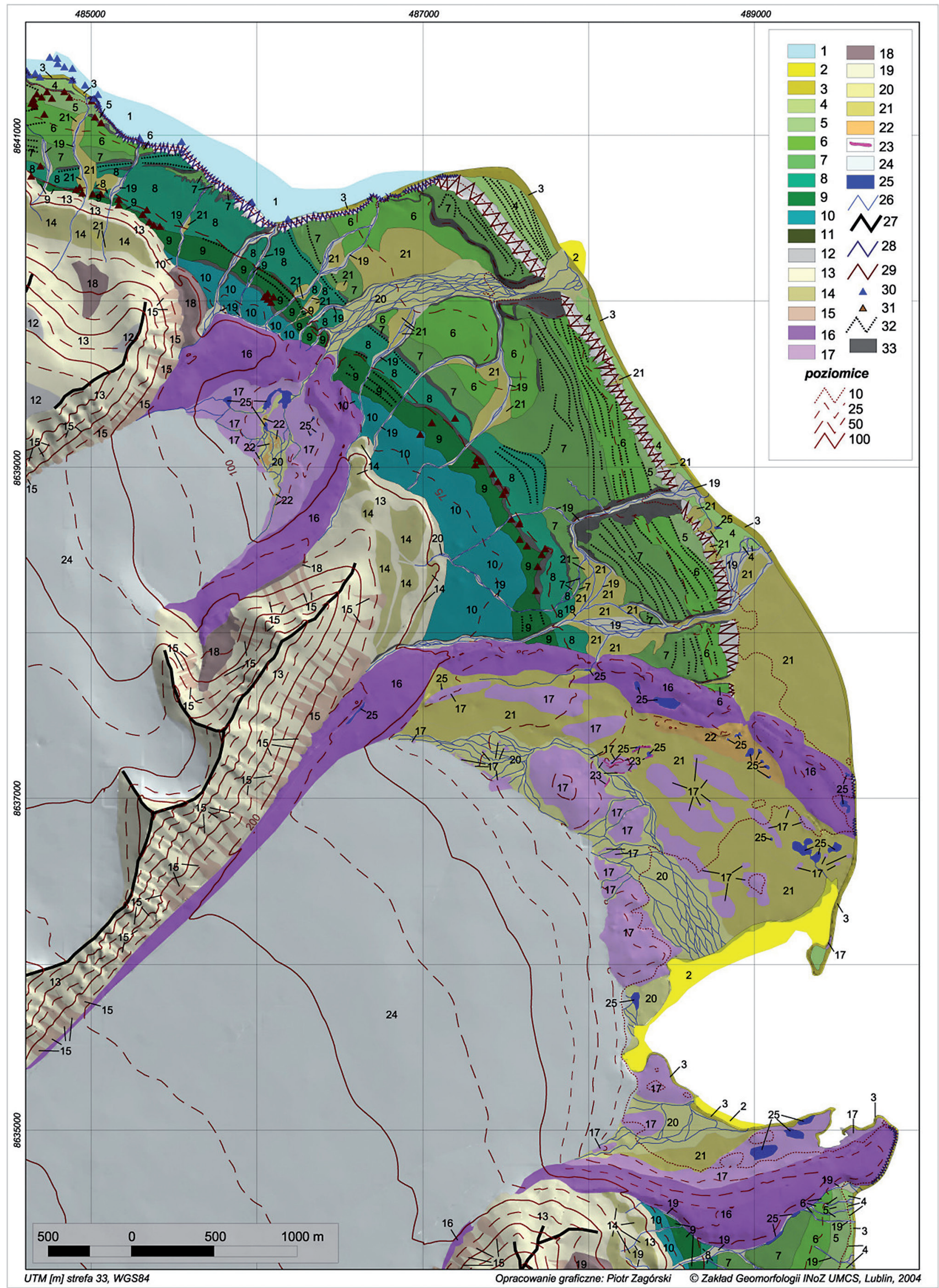


Fig. 4. Geomorphological map of the Calypsostranda region and the Renard Glacier foreland (Zagórski 2004)

1 - contemporary abrasive platform, 2 - floating plane, delta cones, 3 - contemporary stormy bar, 4 - terrace I ( $2-8 \mathrm{~m}), 5$ - terrace II ( $10-20 \mathrm{~m}), 6$ - terrace III (25-30 m), 7 - terrace IV (30-40 m), 8 - terrace V (40-50m), 9 - terrace VI (50-65 m), 10 - terrace VII (70-85 m), 11 - terrace VIII (105 - 120 m), 12 - top flatness, 13 - slopes, 14 - denudation-structural levels, 15 - talus, 16 - ice-moraine bars, accumulation and lateral moraines, 17 - ground and ablation moraines, 18 - stony glaciers, 19 - rubble glaciers (nival moraines), 20 - contemporary planes and outwash taluses, old alluvial taluses and pronival valley bottoms, 21 - old plains and outwash taluses, old alluvial taluses, 22 - kames, 23 - eskers, 24 - glaciers, 25 - lakes, 26 - rivers, 27 - ridges, 28 - active marine cliffs, 29 - dead marine cliffs, 30 - skerries, 31 - paleo-skerries, 32 - storm berms, 33 - edges, 34 - rivers

$\mathrm{m}(\mathrm{V})$ possibly determines the border of maximum sea transgression from the period ca. $12 \mathrm{ka} \mathrm{BP}$, so just after the deglaciation of the last Weichselian glacial maximum (Zagórski 2002, Mangerud, Landvik 2007). It is a slightly inclined plain, in its lower part of accumulation type, and then of abrasion-accumulation. A terrace of 30-40 m (IV) dominates in Calypsostranda. It is an accumulation terrace, almost flat, diversified by fossil storm berms and covered by Quaternary glacial, fluvioglacial and marine deposits which are located on the Paleogene and Precambrian bedrock. Glacial deposits of the middle moraine are related to connected glacier tongues from the Recherche and Van Keulen fjords (Nitychoruk, Dzierżek 1994). In the area of Renardodden, terrace IV is limited by a dead sea cliff, shaped by solifluction. In the Skilvika part, the terrace ends in the form of cliff, intensively eroded by abrasion. In that part of Calypsostranda it circles a vast hollow, where a lower terrace of 25-30 m (III) was specified. Parts of these terraces can be also found between the Scottelva valley and marginal moraines of Renardbreen and feature a slightly inclined accumulation surface with fossil storm banks. Between Calypsobyen and the extramarginal sandur of Renardbreen terrace III changes into the lower terrace of 10-20 $\mathrm{m}$ high (II). The dead cliff surrounding Calypsostranda from the east is the result of intensive abrasion decay of both described terraces III and II in the period of the early Holocene. The lowest terrace $\mathrm{I}$, at 2-8 $\mathrm{m}$ high is a beach along the coastline between vast external sandurs of Renardbreen in the area of Pocockodden and Renardoddne (Harasimiuk 1987). It is made of two old storm banks, separated by a zone of hollows in the form of lagoons. In the zone of Renardodden, as a result of intensive accumulation, several storm berms, fossilised at present, were formed, in a place where many settlements from the $17^{\text {th }}$ and $19^{\text {th }}$ centuries were located (Krawczyk, Reder 1989).

In the neighborhood of Calypsostranda two glacial areas dominate. These are the glaciated valleys of Scott and Renardbreens. The first one, the Scottbreen, reaches a length of $3.5 \mathrm{~km}$ at its axis and its width changes in a range from $1 \mathrm{~km}$ in the lower part to $1.5 \mathrm{~km}$ in the zone of the firn field. The area of the glacier is $4.7 \mathrm{~km}^{2}$ (Zagórski et al. 2012). The Scottbreen fills the valley in a NWSE direction in the lower part, and then becomes meridional. The Scottbreen is surrounded by Bohlinryggen from the east, and by Wijkanderberget from the west. In the south-western area, in the low pass zone, it is connected to Blomlibreen, which fills the upper part of the Blomli valley. The outlet of Scottbreen is closed by a severalmeters high bank of dammed moraine (ice-moraine ridges), which is located on the rock basement, dissected by a gorge which resulted from the outflow of proglacial wa- ters. In the period of Little Ice Age, the Scottbreen functioned entirely as a typical valley glacier without direct connection to the waters of the fjord. The outlet zone of the catchment of the glacial Scott River forms a narrow gorge $(150 \mathrm{~m})$ through the raised marine terraces, where an alluvial fan was formed. At present it is surrounded by a several-meters wide storm bank. The Scottbreen is in a stadium of recession (Zagórski et al. 2008b). Since the Little Ice Age to 2009, the average value of recession of the glacier ice wall has reached approx. 4-5 $\mathrm{m} \cdot \mathrm{a}^{-1}$, and

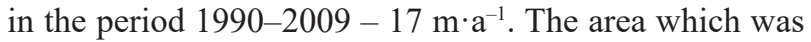
uncovered as the result of deglaciation was $1.42 \mathrm{~km}^{2}$ (in the period 1990-2009-0.58 $\mathrm{km}^{2}$ ).

South of the Scottbreen is the catchment of the Renardbreen. Its present area is $41 \mathrm{~km}^{2}$, and the area of the glacier $-31.3 \mathrm{~km}^{2}(75 \%)$. The vast inland zone closed by the arch a several-meters high dammed moraine (ice-moraine ridges) in the form of several ridges from the foot of Bohlinryggen to Josephbukta, forms the forefield of the glacier. The expanse of the inland zone indicates fast changes related to glacier recession. This process left an unusual abundance of forms and deposits of glacial and fluvioglacial origin (Reder 1996, Reder, Zagórski 2007a, Zagórski et al. 2007). Since the end of Little Ice Age to 2009 continuous recession of the Renardbreen at the rate of $10-11 \mathrm{~m} \cdot \mathrm{a}^{-1}$ (for the period 1990-2009-10.8 $\mathrm{m} \cdot \mathrm{a}^{-1}$ ) was observed (Zagórski et al. 2008a, 2012). During the last few decades vast rock-knobbed inselbergs with a fluted moraine mantle have been uncovered, and the glacier which is gradually retreating to the west lost its connection with the Josephbukta waters.

In the direct forefield of the glaciers, between the retreated glaciers' tongues and frontal moraines (ice-moraine ridges) indicating the maximum range of the last transgression, a morphologically varied zone was formed with such forms as ground and ablation moraines, cut by a channel of proglacial rivers (sandurs), drumlin-like forms and sometimes fissure forms of kames and eskers (Merta 1988, Reder 1996).

\section{Landforms in the vicinity of the Kaffiøyra region $^{5}$}

The north-western part of Oscar II Land, from St. Jonsfjord to the Engelsbukta, which includes the Kaffiøyra area, is formed of two different geological formations. The eastern part is a crystalline rock foundation folded

\footnotetext{
There is a vicinity of the Kaffiøyra Polar Station in Oscar II Land (Nicolaus Copernicus University in Toruń).
} 
in the Caledonian orogenesis, while the western part is the tectonic trench Forlandsundet. The relief of the area and the presence of the individual geological formations on the surface are determined by the course of the tectonic faults. In the area of Oscar II Land, the course of the major faults is from NNW to SSE (Dalmann et al. 1993, Hjelle et al. 1999). In the Kaffiøyra area, the main mountain ridges that define this course include Skredder (775 $\mathrm{m})$ in the massif of Bjørneskanka; Kaldkletten (835 m) in the massif of Jacobsenfjella; Kysa (820 m); Asker (935 $\mathrm{m})$, the highest peak in the Kaffiøyra area; and further to the north-west, Akutt (870 m), Natalie (932 m) and Prinsen $(770 \mathrm{~m})$ in the massif of Prins Heinrichfjella. Along these faults, from the outlined main ridge, the transverse ridges stand. From the north they are: Prins Heinrichfjella (300-345 m), the low sheepback rampart of Gråfjellet, as well as Prinsesseryggen, Jarlsbergryggen, Bolken, Krøvelen, Humpryggen and Bjørneskanka. The western slopes of these ridges suddenly truncate, reaching the line of the young Tertiary fault of the trench Forlandsundet and minor parallel faults (Wójcik 1981, Dallmann 1993, Hjelle et al. 1999).

The mountain ranges in the Kaffiøyra area generally take the form of narrow ridges with narrow crests and very steep slopes. The disintegrative processes caused by the climatic conditions favour the development of slope processes, rock falls, as well as debris and solifluction covers. Snow avalanches and runoff from melting snow and gullies formed alluvial fans at the foot of the mountains. These include:

- steep mountain slopes cut by gullies,

- lower gradients slopes with debris covers,

- slopes with solifluction lobes and sometimes flattened parts in the places dominated by shales.

One part of the ridge of Prinsesseryggen is a $400 \mathrm{~m}$ wide, flat surface where a small glacier developed. The ridge Gråfiellet separating the glaciers Waldemarbreen and Irenebreen was most likely fully covered by ice during the Little Ice Age. As a result, its surface became a sheepback, creating a flat surface about 300 meters wide.

The Kaffiøyra Plain was formed during the post-glacial rebound of Spitsbergen at the turn of the Late Glacial and Holocene periods. According to the study by Niewiarowski et al. (1993), during the early Weichselian the area was much more intensely glaciated than today. The highest abrasive terraces which reached to the level of 65 meters a.s.1., are partly covered by rubble-gravel material.

Between 11.5 and 9 ka BP the land rose and the system of lower terraces, composed primarily of coastal sediments (Niewiarowski et al. 1993) developed. The edges of the marine terraces generally run from NW to SE and are well developed, although heavily cut by small nival valleys and degraded by solifluction processes. There are inselberg outcrops near the mountain ridges of Hecla Hoek formation. On the surface of the old lagoons, periglacial forms have developed, primarily as rocky wreaths, while where there is a lower clay content (e.g. on the edge ramparts) polygons of frost cracks dominate.
Probably about 2,500 years ago, some glaciers first advanced into such areas of the terraced plain. In some places, this glaciation was slightly larger than today (Olszewski 1977, Niewiarowski et al. 1993). The primary morphological elements developed during the advance of the glaciers, and especially during the deglaciation, are river valleys that drain water from the glaciers. They run towards the west or south-west to the Strait of Forland. In addition to the proglacial valleys covered with thin layers of outwash deposits, in the Kaffiøyra region, there are small nival or nival-glacial valleys (Klimaszewski 1960, Sendobry 1982) and a depressions with shallow tundra lakes.

In the foreland of all the glaciers there are ice-moraine ramparts cut by proglacial river gaps. The frontal moraines of the Aavatsmarkbreen and Dahlbreen, terminating in the sea with their several-kilometer-long cliffs, are deposited on the bottom of the bay. They are described in detail by Król et al. (2010). The outer push moraines on Elisebreen are described by Klimaszewski (1960) and Olszewski (1977). Other moraine zones are formed of ice-moraine ramparts of accumulation origins. The depressions behind the external ramparts are formed mostly of an undulating moraine. The deeper and more extensive depressions are occupied by lakes. Along the walls of mountain valleys there are lateral ice-moraine ramparts. Another group of forms are formations of outwash accumulation developed in different areas of the marginal zones and at different altitudes. Sometimes, there are forms of crevasse accumulation, kames and eskers, with the largest esker of this area in the south of the moraine zone of Aavatsmarkbreen (Pietrucień 1977, Niewiarowski 1982).

The coastal strip is varied. In the south, there is a cliff section built of Hecla Hoek rock and a thin cover of marine sediments $(1-2 \mathrm{~m})$. To the north, beyond the mouth of the Andreas River, there is a roughly 10-meter high cliff. Along a stretch of about $200-300 \mathrm{~m}$, the coast is flat, with a sandy-pebble beach and a lagoon behind it. At the mouth of the Elise River, there is a wider beach (levees and lagoons), while a few dozen meters to the east of the shoreline there is a $5 \mathrm{~m}$ fossil cliff of Paleogene formations, covered with a thin layer of Holocene deposits. Along the stretch between the mouths of the rivers Waldemar and Irene there is a low cliff built of glacial deposits (Wójcik 1981). From the mouth of the Waldemar River to Cape Heggodden and in the vicinity of the Nicolaus Copernicus University Polar Station, the seashore is low with the sandy or gravel beach.

\section{Landforms in the vicinity of the Billefjorden ${ }^{6}$}

The complex tectonic history and development of the area in the region of Petuniabukta is currently expressed

\footnotetext{
6 There is a vicinity of the Petunia Polar Station (Adam Mickiewicz University in Poznań).
} 
within four structural units separated by discontinuities (Harland et al. 1974, Harland 1998):

- the oldest unit composed of Precambrian rocks, often referred to as the Hecla-Hoek Succession (pre-Old Red rocks), represented by a variety of primary or metamorphosed crystalline rocks, uplifted during the Caledonian Orogeny, forming steep valley walls and thresholds within them that are resistant to weathering processes (e.g., Sporehogda in the Ebbadalne), as well as lofty massifs (e.g., Faraonfjellet, Birger-Jonssonfjellet)

- a unit consisting of Devonian sedimentary rocks, primarily sandstones and siltstones, surviving only on the west side of the Billefjorden Fault Zone (BFZ). These areas are characterised by flat, broad top surfaces (e.g., Skansen, Wordiekammen), partially occupied by fjeld glaciers (e.g., Jotufonna, Frostisen). They are not particularly steep in either the upper and lower parts of the mountain slopes, and are largely covered with degraded material, with only partially exposed outcrops of the solid basement,

- Carboniferous and Permian rocks are represented by a wide set of conglomerates, sandstones, siltstones, gypsums, anhydrites and dolomites. Horizontal and vertical variation within the rocks of the BFZ is the result of activity during their formation and characteristics of resistance caused morphological diversification, as reflected in sharp ridges and vertical rock walls (e.g., Hultberget), consisting of a multi-coloured "layer cakes" of rock, cut by series of faults, deformed by folding processes, and in places displaced a few hundred meters vertically down the slope surface in the form of large-scale block landslides of whole sections of slopes, which, after massifs and large glacial valleys, they are the third largest individualized landforms in the study area (e.g., the Mimer Valley). Extending out at the foot of cliffs in the vast spaces of the valley slopes are heavily developed talus and alluvial cones (e.g., in the Ebbadalen),

- the youngest geological unit of the Quaternary age is composed of a variety of formations, which include the glaciomarine mud lining the bottom of the fjord, silt on tidalflats, sand and gravel on beaches and raised marine terraces, glacial and fluvioglacial sediments, forefields of glacier retreating after the Little Ice Age, the range of which is the record of their maximum distribution in the Holocene, as well as fluvial cover at the bottoms of valleys and weathering and deluvial covers on hilltops and mountain slopes.

Only in a few places is the pre-Holocene layer revealed, preserved as elevated marine terraces, recognized in Hørbyedalen (Karczewski, Rygielski 1989), Ragnardalen (Stankowski et al. 1989), Ebbadalen (Kłysz et al. 1988.1989, Szczuciński, Rachlewicz 2003) and the most well-known outcrops on Kapp Ekholm, in the middle part of the east coast of Billefjorden (Lavrushin 1969, Boulton 1979, Mangerud, Svendsen 1992, Mangerud et al. 1998). Throughout the Holocene, there has been a steady gla- cial isostatic uplift of up to $60 \mathrm{~m}$ a.m.s.l., and sediments from before the last glacial period in the young Pleistocene are found at a height of up to $90 \mathrm{~m}$ a.s.l. (Kłysz et al. 1988, 1989, Szczuciński, Rachlewicz 2003). As a result of these processes, along the coast of the fjord elevated levels of well-preserved marine terrace are developed, built mainly of gravel and sandy material, which can have larger or very fine grains locally, accumulated in a marginal (lagoon) conditions (Rachlewicz, Szczuciński 2003, Samołyk, Tylkowski 2009, Long et al. 2012). The thickness of these deposits is generally 1-2 $\mathrm{m}$, but in some cases (e.g., on the east coast of Petuniabukta at the foot of Wordiekammen), well-preserved, built-up spit-like forms can reach up to $20 \mathrm{~m}$.

During the Holocene, extensive slope covers and alluvial fans also developed. The thickness of the sediments from which these forms are built is visible in a series of erosion undercuts and cuts, reaching up to $10 \mathrm{~m}$. These consist of poorly sorted, coarse-grained, poorely-rounded series of local rock, interbedded in places with inserts of washed sand and gravel (Kostrzewski, Zwoliński 2003). Inside the slope and talus covers, burried soils are found that date back to the middle Holocene (Rachlewicz 2009), indicating a complex evolution of the denudation-weathering system's development, with milder climatic conditions and stabilization of slopes.

In the literature, it is widely accepted that the spread of the ice cover during the Holocene was much less extensive than today (e.g., Werner 1993, Humlum et al. 2005). The climate began a cooling about 3000 years ago that reached its peak during the Little Ice Age, and ended at the turn of the 19th and 20th centuries, when once again, a trend began toward climate-induced glacier retreat (e.g., Hagen et al. 2003, Rachlewicz et al. 2007a). The recession of glacier fronts is taking place at a rate of a few to approx. $50 \mathrm{~m} \mathrm{a}^{-1}$, and is manifested in the generation of marginal zones, where sediments are deposited at thicknesses reaching an average of 2-2.5 m, mainly in the form of a series of ice-cored moraine ridges (Karczewski 1989, Rachlewicz 2009, Ewertowski et al. 2011). Among other the types of glacial deposits basal tills are found with traces of flutings and pushed-moraine deposits (Boulton 1970, Rachlewicz 2009, Szuman and Kasprzak 2010, Evans et al. 2012). As a result of the intense activity of meltwater, a range of surfaces and forms of fluvioglacial deposits have formed, which include the esker chains, kame hills and terraces, and, above all, vast outwash areas (e.g., very well developed in the foreland of the Hørbyebreen) (Rachlewicz, Rygielski 1988, Rachlewicz 1989, 2009, Karczewski, Kłysz 1994, Evans et al. 2012) The latter, within which the thickness of the sedimentary series reaches $20 \mathrm{~m}$, are the most important reservoirs of Quaternary material, retaining sediment being transported toward the fjord's sedimentary basin (Rachlewicz 2009).

The vast majority of the glaciers surrounding Billefjorden terminate on land, while the rivers draining water from their fronts travel through tidal flats of up to 


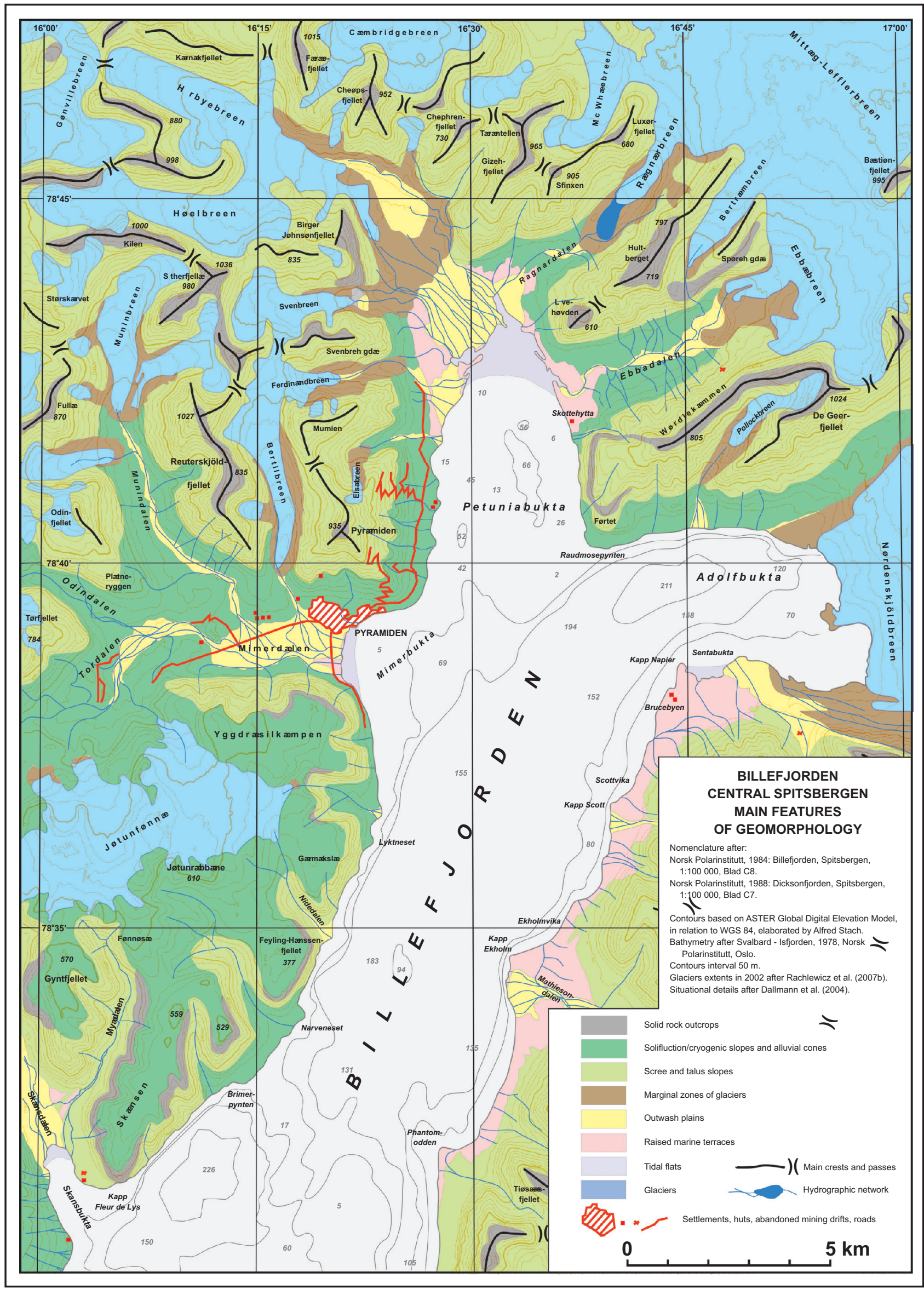

Fig. 5. Outline of geomorphological features in the vicinity of the Billefjorden (Rachlewicz 2009) 
$2 \mathrm{~km}$ in length (e.g., in Petunia Bay). They represent important areas for the transfer and deposition of sediments formed by the interaction of marine tides with amplitudes of up to $1.5 \mathrm{~m}$, waves and sea ice.

The intertidal zone is composed mainly of sandy and muddy sediments, which are delivered to the outer zone of tidal plain at a rate equal reaching $90 \mathrm{~g} \mathrm{~m}^{-2} \mathrm{~h}^{-1}$, with a positive balance in the sediment surface of the tidal plane. In the depths of the bay, sedimentation the rate decreases, reaching a value of approx. $0.2 \mathrm{~mm}$ per year in the central part of the fjord basin (Szczuciński et al. 2009). The bottom of the fjord is lined with glaciomarine mud, with a thickness of up to $25 \mathrm{~m}$ in Adolf Bay in front of the Nordenskiöldbreen.

The coastal area, valleys and mountain ranges surrounding Billefjorden reveals a variety of interesting and unique forms (Fig. 5). The multiplicity of landscapes and their inter-relationships reflect the varied conditions that led to their formation, the intensity of the geomorphic processes and their age. The bulk of the assumptions about the area's landscape is associated with widespread Quaternary glaciation, the essential impact of which ended approx. 10,000 years BP. The most spectacular expression of the repetition of this glaciation several times in the past, resulting in an ice sheet that covered the Barents Sea and Spitsbergen, are the island's large valleys and fjords. In addition to the glacial deposit covers described above, occurring in the form of individualised patches, no identifiable landforms have survived from this period. The last episode of glacial covering is associated with the cooling of the climate in the late Holocene, during the so-called Little Ice Age (15th-19th century). As result of it, there was a marked reconstruction of the geomorphological architecture, with distinct glacial marginal zones being created in the valleys, which for over a hundred years were subject to a continuous process of recession. In the Billefjorden basin, which is approximately $40 \%$ glacier covered (Hagen et al. 1993), among the 23 major glaciers, in only one case has it been irrefutably confirmed the occurrence of a surge after the Little Ice Age (Skansdalsbreen). Some conditions, such as undulated, sharp- edged, non-ice-cored moraines, suggest the possibility of surging by other glaciers, with the best evidence for the existence of this phenomenon being found in the marginal zone of the Hørbyebreen (Karczewski 1989, Rachlewicz 2009, Evans et al. 2012). Processes indicating the non-existence of surging are characterized by the development of marginal zones in the form of extensive sequences of icecored moraines (such as the Ragnarbreen and Ebbabreen). The dynamics of deglaciation is also closely related to the characteristics of the bedrock, for which inequality in the form of thresholds and steps composed primarily of resistant crystalline and metamorphic rocks, cutting off the flow of ice from the higher parts of glacier covered valleys causing an extreme thinning of the glaciers, and finally their decay and filling in with sediment detritus. Part of the marginal zones (e.g., the Hørbyebreen, Svenbreen, and Ebbabreen) lie beneath walls several dozen to a hundred and several dozen metres in height which clearly show signs of intense exaration in the form of glacially polished rock walls and the regular forms of roche moutonnée.

Glacial valley slopes are also characterized by a very pronounced exaration morphology with undercuts forming glacial shoulders suspended 50 metres or more above the floors of valleys and glacial striae on flattened rock surfaces (e.g., in the Ebbadalen). In the upper parts of the valleys, the original level of ice is marked by the presence of clearly marked, extensive lateral moraine ridges (e.g., Hørbyebreen and Ragnarbreen). Marginal zones surround retreating glaciers with sequences of asymmetrical moraine semi-ovals. Moraine ridges reach a maximum height of 20-25 $\mathrm{m}$ above the valley floor and are surrounded by radiating or descending in narrower parts of valleys surfaces of outwash planes. In the lowerings formed between the moraine ridges or in their backfields exarated to a lower level, areas of fluvioglacial sedimentation of internal sandurs (e.g., Hørbyebreen) or marginal lakes deposition (e.g., Ragnarbreen) are formed (Rachlewicz, Rygielski 1988, Rachlewicz 2009, Ewertowski et al. 2011). Some parts of the terminal moraines are a continuation of the medial moraines, which divide glacial tongues depending on the complexity of the glacial basin and the directions of the glaciers' feeding.

Above the glaciers covered valley floors, usually only in the upper parts, rock walls rise up, which are subjected to intense weathering processes (e.g., Ebbadalen, Mathiesondalen). Talus cones, alluvial fans and solifluction slopes extend out at the foot of cliffs beneath the fjeld surface, the system of which is structurally conditioned, depending on the diversity of resistance, (e.g., in Ebbadalen and Adolfbukta). The cover, which is a mosaic comprised of particles ranging from boulders to sandy silt, is converted by a complex set of morphogenetic factors that cause the formation of mass movements, which includes avalanches of snow and rock, as well as local surface runoff and occasional streams (Rachlewicz 2009, Marciniak and Dragon 2010). Significant changes in the summit and hillside surfaces occur due to the effects of periglacial processes. The Petuniabukta area is under the influence of continuous permafrost with an active layer that thaws in the summer to a depth of 1.5-2.5 m, depending on the type of deposits and the elevation a.s.l. (Gibas i in. 2005, Rachlewicz and Szczuciński 2008, Mazurek et al. 2012). The dry climate of the interior of the island (Kostrzewski et al. 1989, Rachlewicz 2009) results in less distinct periglacial effects compared to the west coast of Spitsbergen. The best developed polygonal soil and stone circles can be observed on the flat surfaces of peaks rising above $400 \mathrm{~m}$ a.s.l. (e.g., in the Skansen and Wordiekammen massifs), where the amount of rainfall is $20-25 \%$ higher than at the sea level. Also commonly occurring in such privileged places are weathered-glacial clay covers (Rachlewicz 2009). The shallow residual level of super-permafrost groundwater during the summer causes common solifluction processes on valley slopes (e.g., 
Ebbadalen) and mountain areas (e.g., Wordiekammen, DeGeerfjellet) (Dragon and Marciniak 2010, Marciniak et al. 2011). At the foot of the slopes, wetlands appear supplied periodically by springs fed by melting permafrost (Szczucińska 2011, Szczucińska, Wasilewski 2013).

The lower sections of the valleys are occupied by levels of raised marine terraces (Feylig-Hanssen 1955, Kłysz et al. 1989, Stankowski et al. 1989, Rachlewicz, Szczuciński 2003) on which occur small tundra lakes (Zwoliński et al. 2007, 2008, Mazurek et al. 2012). The oldest terraces in the Ebba Valley have been $\mathrm{C}^{14}$ dated to more than 37,000 years BP, corresponding to the glaciation before the last Svalbard-Barents Sea ice-sheet maximum extent. Younger raised marine terraces occur at a height of $45 \mathrm{~m}$ a.m.s.l. in the sequence of the Holocene, marked by thresholds and slopes, which are remnants of the former coast with a local drop on the order of $5 \mathrm{~m}$ (e.g., in Petuniabukta, Phantomodden or Kapp Ekholm).

Coastal forms, including raised marine terraces, and, especially, large areas of overlapping outwash surfaces with flood terraces and tidal plains are the main field for aeolian activity (Paluszkiewicz 2003 Górska-Zabielska 2008). As a result, clear forms are created with a deflationary and sometimes thick aeolian cover (e.g., in the central part of Ebbadalen), which often are initiated by the incidence of clumps of tundra vegetation. This yields sand shadows and parabolic proto-dunes. On surfaces of aeolian cover sands form clear wind ripplemarks. All forms of aeolian accumulation, as well as individual ventifacts, and results in the form of corrosion on the surfaces of rocks reflect the activities of the dominant northern and north-eastern winds of a morphogenic character, the transport capacity of which is expressed at wind speeds in excess of $5 \mathrm{~m} \mathrm{~s}^{-1}$ (Paluszkiewicz 2003); this applies especially to the strongest winds, blowing from the north (Górska-Zabielska 2008).

On the west coast of Petuniabukta and Mimerbukta, one can find in the environment some of the most visible traces of poorly considered human economic activity on Billefjorden, and even Svalbard, which caused significant damage to the landscape. These are mainly what remains of the former coal mines near the town of Pyramiden, including tunnels and heaps ore and combustible materials situated at their mouth, a network of dirt roads and local contamination of the subsoil with petroleum compounds (Gulińska et al. 2003, Buchwał 2008). The abandoned mine in Pyramiden bears testimony to the damage caused by humans to the polar landscape. In recent years, there have also been signs of continued tourism activity in the form of paths and signs of camping (Buchwał 2008, Tomczyk, Ewertowski 2010, Rachlewicz et al. 2013).

\section{Conclusions}

Geographical location of Spitsbergen determines its individuality as a polar zone region. The glacial history of Spitsbergen suggests that during the Pleistocene glaci- ations all of the island's contemporary landmass, together with the Barents Sea shelf, was covered by a single ice cap, and then glacioisostatically and eustatically raised. This provides a basis for comparative study of the time relations between events and the development of these areas, which could indicate a high degree of morphological and sedimentological convergence. In fact, local conditions cause a greater diversification of Spitsbergen's landmass than could result from regional or trans-regional conditions.

The accelerated ablation of Spitsbergen's glaciers and the increasing rate of melting of permafrost (Kostrzewski et al. 2007, Zwoliński et al. 2008) are causing accelerated growth in periglacial, proglacial and paraglacial areas (in the sense of Slaymaker 2011) at the damage of glaciated areas. The progressive process of decay in surface and underground glaciation is influencing to the acceleration of geomorphic activity in Spitsbergen. Among the morphogenetic processes increasing in significance are weathering, abrasion, deflation, and solutes and sediment transport processes on slopes and in river channels, chemical and mechanical denudation, and a wide range of processes modelling the marginal zones of glaciers. The rate of these changes in the natural environment of Spitsbergen's geoecosystems is also intensified by human activity.

\section{References}

Andrzejewski L., Stankowski W., 1981. Recesja Lodowca Vitkovski na tle analizy jego strefy marginalnej (południowy Spitsbergen). VIII Sympozjum Polarne. Materiały. Sosnowiec: 139-142.

Bednarek J., Rudowski S., Zalewski S.M., 1993. The tectonic sketch of the offshore area within Hornsund region, Spitsbergen. In: J. Repelewska-Pękalowa, K. Pękala (eds.), XX Polar Symposium. Man Impact on Polar Environment, Lublin, June 3-5: 293-297.

Birkenmajer K., 1982. Talus moraines in South Spitsbergen and comparison with East Greenland. Results of Investigation of the Polish Scientific Spitsbergen Expeditions 4. Acta Univ. Wratisl. 525: 29-38.

Boulton G.S., 1970. On the deposition of subglacial and melt-out tills at the margin of certain Svalbard glaciers. J. Glac. 9: 231-245.

Boulton G.S., 1979. Glacial history of the Spitsbergen archipelago and the problem of a Barents Shelf ice sheet. Boreas 8: 31-57. http://dx.doi.org/10.1111/j.1502-3885.1979.tb00429.x

Brázdil R. (ed.), Chmal H., Kida J., Klementowski J., Konečný M., Pereyma J., Piasecki J., Prošek P., Sobik M., Szczepankiewicz-Szmyrka A., 1988. Results of investigations of the geographical research expedition Spitsbergen 1985. Univerzita J.E. Purkyně, Brno.

Buchwał A., 2008. Funkcjonowanie dróg w górskim systemie stokowym masywu Pyramiden na Spitsbergenie. Prace Geograficzne UJ 120: 9-17.

Chmal H., 1984. Marginal zone of Werenskiold Glacier 1:20 000. In: A. Karczewski, A. Andrzejewski, H. Chmal, J. Jania, P. Kłysz, A. Kostrzewski, L. Lindner, L. Marks, K. Pękala, M. Pulina, S. Rudowski, W. Stankowski, T. Szczypek, E. Wiśniewski (eds.), Hornsund, Spitsbergen. Geomorphology 1:75 000. Uniwersytet Śląski, Katowice: 1 sheet.

Chmal H., 1987. Pleistocene sea level changes and glacial history of the Hornsund area, Svalbard. Polar Research 5: 269-270. http://dx.doi.org/10.1111/j.1751-8369.1987.tb00545.x

Chmal H., Kida J., Konečný M., Traczyk A., 1988. Geomorphological Map of the Werenskiold Glacier Region. In: R.Brázdil (ed.), Results of investigations of the geographical research expedition Spitsbergen 1988. Univerzita J.E. Purkyně, Brno. 
Dallmann W.K., Andersen A., Bergh S.G., Maher H.D., Jr., Ohta Y., 1993. Tertiary fold-and-thrust belt of Spitsbergen, Svalbard. Norsk Polarinstitutt, Meddelelser 123: 1-46.

Dragon K., Marciniak M., 2010. Chemical composition of groundwater and surface water in the Arctic environment (Petuniabukta region, central Spitsbergen). Joural of Hydrology 386: 160-172. http://dx.doi.org/10.1016/j.jhydrol.2010.03.017

Evans D.J.A., Strzelecki M., Milledge D.G., Orton C., 2012. Hørbyebreen polythermal glacial landsystem, Svalbard. Journal of Maps $8(2): 146-156$ http://dx.doi.org/10.1080/17445647.2012.680776

Ewertowski M., Kasprzak L., Szuman I., Tomczyk A.M., 2011. Controlled ice-cored moraines: sediments and geomorphology. An example from Ragnarbreen, Svalbard. Zeitshrift für Geomorphologie, 56(1): 53-74 http://dx.doi.org/10.1127/0372-8854/2011/0049

Feyling-Hanssen R.W., 1955. Stratigraphy of the marine late-Pleistocene of Billefjorden, Vestspitsbergen. Norsk Polarinstitutt Skrifter 107: $1-186$

Gibas J., Rachlewicz G., Szczuciński W., 2005. Application of DC resistivity soundings and geomorphological surveys in studies of modern Arctic glacier marginal zones, Petuniabukta, Spitsbergen. Pol. Polar Res. 26(4): 239-258.

Górska-Zabielska M., 2008. Formy eoliczne na przedpolu lodowca Ebba, środkowy Spitsbergen. In: E. Smolska, D. Giriat (eds.), Rekonstrukcja dynamiki procesów geomorfologicznych - formy rzeźby i osady. Wyd. Uniwersytetu Warszawskiego, Warszawa: 199-204.

Gulińska J., Rachlewicz G., Szczuciński W., Barałkiewicz D., Kózka M., Bulska E., Burzyk M., 2003. Soil Contamination in High Arctic Areas of Human Impact, Central Spitsbergen, Svalbard. Pol. J. Environ. Stud. 12(6): 701-707.

Hagen J.O., Kohler J., Melvold K., Winther J.-G., 2003. Glaciers in Svalbard: mass balance, runoff and freshwater flux. Polar Res. 22(2): 145-159. http://dx.doi.org/10.1111/j.1751-8369.2003.tb00104.x

Harasimiuk M., 1987. Współczesny rozwój wybrzeży południowego Bellsundu i fiordu Recherche (Zachodni Spitsbergen). XIV Sympozjum Polarne. Lublin: 99-102.

Harasimiuk M., Jezierski W., 1988. Typy wybrzeży południowego Bellsundu. Coast types of South Bellsund. Wyprawy Geograficzne na Spitsbergen. UMCS, Lublin: 173-181.

Harasimiuk M., Jezierski W., 1991. Type of coasts of south Bellsund (West Spitsbergen) and tendency of their evolution. Wyprawy Geograficzne na Spitsbergen. UMCS, Lublin: 17-22.

Harland W.B., 1998. The geology of Svalbard. Geol. Soc. Mem., M0017: 1-529.

Harland W.B., Cutbill J.L., Friend P.F., Gobbett D.J., Holliday D.W., Maton P.I., Parker J.R., Wallis R.H., 1974. The Billefjorden Fault Zone, Spitsbergen. Norsk Polarinstitutt Skrifter 161: 1-89.

Hjelle A., Piepjohn K., Saalmann K., Ohta Y., Salvigsen O., Thiedig F., Dallmann W.K., 1999. Geological Map - Svalbard 1:100 000, A7G, Kongsfjorden. Norsk Polarinstitut, Tromsø.

Humlum O., Elberling B., Hormes A., Fjordheim K., Hansen O.H., Heinemeier J., 2005. Late-Holocene glacier growth in Svalbard, documented by subglacial relict vegetation and living soil microbes. The Holocene 15(3): 396-407. http://dx.doi.org/10.1191/0959683605h1817rp

Jahn A., 1959. Postglacjalny rozwój wybrzeży Spitsbergenu. Czasopismo Geograficzne 30: 245-262.

Jahn A., 1961. Quantitative analysis of some periglacial processes in Spitsbergen. Zesz. Nauk. Uniw. Wrock. B5.

Jahn A., 1967. Some features of mass movement on Spitsbergen slopes. Geografiska Annaler A(49): 213-225

Jania J., Głowacki P., Bukowska-Jania E., Kolondra L., Perski Z., Pulina M., Piechota A.M., Szafraniec J., Dobiński W., Piwowar B.A., 2004. Lodowce otoczenia Hornsundu. In: A. Kostrzewski, M. Pulina, Z. Zwoliński (eds.), Warsztaty Glacjologiczne Spitsbergen 2004. Glacjologia, geomorfologia i sedymentologia środowiska polarnego Spitsbergenu. Sosnowiec-Poznań-Longyearbyen: 68-97.

Karczewski A., 1989. The development of the marginal zone of the Hørbyebreen, central Spitsbergen. Pol. Polar Res. 10(3): 371-377.

Karczewski A., 2004. Obraz geomorfologiczny obszarów niezlodowaconych fiordu Hornsund. In: A. Kostrzewski, M. Pulina, Z. Zwoliński (eds.), Glacjologia, geomorfologia i sedymentologia środowiska polarnego Spitsbergenu. Stowarzyszenie Geomorfologów Polskich, Sosnowiec-Poznań-Longyearbyen: 109-122.

Karczewski A., Andrzejewski L., Chmal H., Jania J., Kłysz P., Kostrzewski A., Lindner L., Marks L., Pękala K., Pulina M., Rudowski S., Stankowski W., Szczypek T., Wiśniewski E., 1984. Hornsund, Spitsbergen. Geomorfologia - geomorphology. 1:75 000. Uniwersytet Śląski, Katowice.

Karczewski A. (ed.), Borówka M., Gonera P., Kasprzak L., Kłysz P., Kostrzewski A., Lindner L., Marks L., Rygielski W., Stankowski W., Wojciechowski A., Wysokiński L., 1990. Geomorphology - Petuniabukta, Billefiorden, Spitsbergen, 1:40 000. Uniwersytet im. Adama Mickiewicza, Poznań.

Karczewski A., Kłysz P., 1994. Lithofacies and structural analysis of crevasse filling deposits of the Svenbreen foreland (Petuniabukta, Spitsbergen). 21 ${ }^{\text {st }}$ Polar Symposium, Warszawa, 23-24.09.1994: 123-133.

Karczewski A., Kostrzewski A., Marks L., 1981a. Morphogenesis of subslope ridges north of Hornsund, Spitsbergen. Polish Polar Research 2(1-2): 29-38.

Karczewski A., Kostrzewski A., Marks L., 1981b. Raised marine terraces in the Hornsund area (northern part), Spitsbergen. Polish Polar Research 2(1-2): 39-50.

Karczewski A., Rygielski W., 1989. The problem of glacial deposits in the Hörbyedalen and an attempt at their chronostratigraphy, central Spitsbergen. Polish Polar Research 10(3): 401-409.

Kasprzak M., 2012a. Morfometria, formy i osady doliny Steinvik (SW Spitsbergen). In: E. Krawczyk, A. Styszyńska (eds.), Streszczenia referatów i posterów. XXXIV Sympozjum Polarne. Sosnowiec: 84.

Kasprzak M., 2012b. Rozwój stoku trójdzielnego w świetle pomiarów młotkiem Schmidta - przykład JensErikfjellet, Ziemia Wedela Jarlsberga. In: E. Krawczyk, A. Styszyńska (eds.), Streszczenia referatów i posterów. XXXIV Sympozjum Polarne. Sosnowiec: 85.

Klementowski J., Konečný M., 1988. Genesis and development of hydrolaccoliths in the region between Werenskiold and Hans Glaciers during 1974-1985. In: R. Brázdil (ed.), Results of investigations of the geographical research expedition Spitsbergen 1985. Univerzita J.E. Purkyně, Brno: 272-284

Klimaszewski M., 1960. Studia geomorfologiczne w zachodniej części Spitsbergenu między Kongs-fjorden a Eidem-bukta. Zesz. Nauk. UJ 32, Prace Geograficzne 1.

Kłysz P., Lindner L., 1980. Evolution of the marginal zone and the forefield of the Bunge Glacier, Spitsbergen. Acta Geol. Pol. 32(3-4): 253-266.

Kłysz P., Lindner L., Makowska A., Marks L., Wysokiński L., 1988. Late Quaternary glacial episodes and sea level changes in the northeastern Billefjorden region, Central Spitsbergen. Acta. Geol. Pol. 38(1-4): 107-123.

Kłysz P., Lindner L., Marks L., Wysokiński L., 1989. Late Pleistocene and Holocene relief remodeling in the Ebbadalen-Nordenkiöldbreen region in Olav V Land, central Spitsbergen. Pol. Polar Res. 10(3): 277-301.

Kostrzewski A., Kapuściński J., Klimczak R., Kaniecki A., Stach A., Zwoliński Z., 1989. The dynamics and rate of denudation of glaciated and non-glaciated catchments, central Spitsbergen. Pol. Polar Res. 10(3): 317-367.

Kostrzewski A., Rachlewicz G., Zwoliński Z., 2007. Zmiany funkcjonowania geoekosystemów lądowych Arktyki. In: A.A. Marsz, A. Styszyńska (eds.), Zmiany klimatyczne w Arktyce i Antarktyce w ostatnim pięćdziesięcioleciu XX wieku i ich implikacje środowiskowe AM, Gdynia: 289-309.

Kostrzewski A., Zwoliński Z., 2003. Środowisko sedymentacyjne stożków piargowych. In: A. Kostrzewski, Z. Zwoliński (eds.), Funkcjonowanie dawnych i współczesnych geoekosystemów Spitsbergenu. Stowarzyszenie Geomorfologów Polskich: 49-52.

Kowalska A., Sroka W., 2008. Sedimentary environment of the Nottinghambukta delta, SW Spitsbergen. Polish Polar Research 29(3): 245-259.

Krawczyk A., Reder J., 1989. Pozostałości osadnictwa sezonowego w północno-zachodniej części Ziemi Wedela Jarlsberga. Wyprawy Geograficzne na Spitsbergen. UMCS, Lublin: 131-146. 
Król M., Grześ M., Sobota I., Ćmielewski M., Jaworski T., 2010. Submarine evidence of the Late Weichselian maximum extent and the Little Ice Age (LIA) glacier limits in the St. Jonsfjorden region (Svalbard). Bulletin of Geography - Physical Geography Series 3: 87-102.

Lavrushin J.A., 1969. Tchetvertnye osadki Spitsbergena. Poiski VII Kongresa INQUA. Nauka, Moskva: 1777.

Lindner L., Marks L., Roszczynko W., Semil J., 1991. Age of raised marine beaches of northern Hornsund Region, South Spitsbergen. Polish Polar Research 12(2): 161-182.

Lipert C., 1961. Lodowiec Werenskiold 1:5 000 - strefa czołowa. Mapa. Wojskowa Służba Topograficzna, Warszawa: 1 sheet.

Long A.J., Strzelecki M.C., Lloyd J.M., Bryant C.L., 2012. Dating High Arctic Holocene relative sea level changes using juvenile articulated marine shells in raised beaches. Quaternary Science Reviews 48: 61-66. http://dx.doi.org/10.1016/j.quascirev.2012.06.009

Manecki A., Czerny J., Kieres A., Manecki M., Rajchel J., 1993. Geological Map of the SW Part of the Wedel Jarlsberg Land, Spitsbergen, 1:25 000. AGH, Kraków: 1 sheet.

Mangerud J., Dokken T., Hebbeln D., Heggen B., Ingólfsson O., Landvik J.O., Mejdahl V., Svendsen J.I., Vorren T.O., 1998. Fluctuations of the Svalbard-Barents sea ice sheet during the last 150000 years. Quaternary Science Review 17: 11-42. http://dx.doi.org/10.1016/S0277-3791(97)00069-3

Mangerud J., Landvik J.Y., 2007. Younger Dryas cirque glaciers in western Spitsbergen: smaller than during the Little Ice Age. Boreas 36: 278-285. http://dx.doi.org/10.1111/j.1502-3885.2007.tb01250.x

Mangerud J., Svendsen J.I., 1992. The last interglacial-glacial period on Spitsbergen, Svalbard. Quaternary Science Reviews 11: 633-664. http://dx.doi.org/10.1016/0277-3791(92)90075-J

Marciniak M., Dragon K., 2010. The influence of groundwater discharge on the runoff of an Arctic stream (Ebba River, central Spitsbergen). Biuletyn Państwowego Instytutu Geologicznego 441: 93-100.

Marciniak M., Dragon K., Chudziak Ł., 2011. O zasilaniu woda gruntową rzeki polarnej Ebba w rejonie zatoki Petunia na środkowym Spitsbergenie. Biuletyn Państwowego Instytutu Geologicznego 445: 371-382.

Mazurek M., Paluszkiewicz R., Rachlewicz G., Zwoliński Z., 2012. Variability of water chemistry in tundra lakes, Petuniabukta coast, central Spitsbergen, Svalbard. The Scientific World Journal. http://dx.doi.org/10.1100/2012/596516

Merta T., 1988. Elementy kierunkowe w morenie typu "fluted" na przedpolu lodowca Renarda (Spitsbergen). XV Sympozjum Polarne. Wrocław: 76-81.

Niewiarowski W., 1982. Morphology of the forefield of the Aavatsmark Glacier (Oscar II Land, NW Spitsbergen) and phases of its formation. Acta Universitatis Nicolai Copernici, Geografia 16(51): 15-43.

Niewiarowski W., Pazdur M.F., Sinkiewicz M., 1993. Glacial and marine episodes in Kaffiøyra, North-Western Spitsbergen, during the Weichselian (vistulian) and the Holocene. Polish Polar Research 14(3): 21-34.

Nitychoruk J., Dzierżek J., 1994. Probable occurrence of allochthonous rocks in Calypsostranda (Bellsund). XXI Polar Symposium. Warszawa: $159-162$.

Nitychoruk J., Ozimkowski W., Szczęsny R., 1989. Construction of morphological profiles of raised marine beaches in Spitsbergen. Polish Polar Research 10,1: 73-79.

NOS [Norges offisielle statistikk], 2009. Statistics Norway. Online: http:// www.ssb.no/english/subjects/00/00/20/svalbard en/ - 1.03.2013.

Olszewski A., 1977. Geomorphological investigations of the marginal zone of Elise Glacier. Acta Universitatis Nicolai Copernici, Geografia 13: 67-74.

Owczarek P., 2010. Dendrochronological dating of geomorphic processes in the High Arctic. Landform Analysis 14: 45-56.

Paluszkiewicz R., 2003. Zróżnicowanie natężenia transportu eolicznego w warunkach polarnych jako efekt zmienności czynników meteorologicznych na przykładzie doliny Ebby (Petuniabukta, Billefjorden, Spitsbergen środkowy). Mat. XXIX Symp. Pol., Kraków: 235-238.

Pękala K., 1987. Rzeźba i utwory czwartorzędowe przedpola lodowców Scotta i Renarda (Spitsbergen). XIV Sympozjum Polarne. Lublin: 84-87.
Pękala K., Reder J., 1989. Rzeźba i osady czwartorzędowe Dyrstaddalen i Lognedalen. Wyprawy Geograficzne na Spitsbergen. UMCS, Lublin: 159-161.

Pękala K., Repelewska-Pękalowa J., 1988. Główne rysy rzeźby i osady czwartorzędowe doliny Chamberlin (Spitsbergen). Wyprawy Geograficzne na Spitsbergen. UMCS, Lublin: 161-172.

Pietrucień C., 1977. Hydrological investigations of moraine lakes in the forefield of Aavatsmark Glacier. Acta Universitatis Nicolai Copernici, Geografia 13: 127-144.

Pulina M., 2004. Zjawiska krasowe południowego Spitsbergenu. In: A. Kostrzewski, M. Pulina, Z. Zwoliński (eds.), Glacjologia, geomorfologia i sedymentologia środowiska polarnego Spitsbergenu. Stowarzyszenie Geomorfologów Polskich, Sosnowiec-Poznań-Longyearbyen: $124-128$.

Rachlewicz G., 1989. Budowa i klasyfikacja łach w korytach rzek roztokowych na przedpolu lodowca Hørbye - Spitsbergen Środkowy. Mat. XVI Symp. Pol., Toruń: 122-124.

Rachlewicz G., 2009. Contemporary sediment fluxes and relief changes in high Arctic glacierized valley systems (Billefjorden, Central Spitsbergen). Wyd. Nauk. UAM, Poznań, ser. Geografia 87: 1-204.

Rachlewicz G., Baran J., Pleskot K., 2013. Rozwój turystyki w obszarach polarnych na przykładzie Svalbardu. Prace Państwowej Wyższej Szkoły Zawodowej w Gorzowie, in press.

Rachlewicz G., Kostrzewski A., Kasprzak L., Zwoliński Z., 2007a. Funkcjonowanie geoekosystemów glacjalnyh i peryglacjalnych w otoczeniu zatoki Petunia (Spitsbergen Środkowy). In: A. Gaździcki, W. Majewski, P. Głowacki (eds.), Struktura, ewolucja i dynamika litosfery, kriosfery i biosfery w europejskim sektorze Arktyki oraz w Antarktyce - materiały sesji sprawozdawczej grantu PBZ-KBN-108/ P04/2004. Wyd. Inst. Geofizyki PAN: 185-188.

Rachlewicz G., Rygielski W., 1988. Strefa proksymalna sandru marginalnego lodowca Hörbye (Spitsbergen Środkowy). Spektrum 1-2 /I/: 203-215.

Rachlewicz G., Szczuciński W., 2003. Czwartorzędowe podniesione osady morskie centralnego Spitsbergenu - nowe dane. Mat. IV Symp. Geneza, litologia i stratygrafia utworów czwartorzędowych, Poznań: 72.

Reder J., 1996. Evolution of marginal zones during glacial retreat in northwestern Wedel Jarlsberg Land, Spitsbergen. Polish Polar Research 17(1-2): 61-84.

Reder J., Zagórski P., 2007a. Recession and development of marginal zone of the Renard Glacier. Geomorphology of the southern side of Bellsund. In: Field trip guide "Geomorphology of the southern side of Bellsund". Landform Analysis 5: 163-167.

Reder J., Zagórski P., 2007b. Recession and development of marginal zone of the Scott Glacier. Geomorphology of the southern side of Bellsund. In: Field trip guide "Geomorphology of the southern side of Bellsund". Landform Analysis 5: 175-178.

Salvigsen O., Elgersma A., 1993. Radiocarbon dating of deglaciation and raised beaches in north-western Sørkapp Land. Zeszyty Naukowe UJ, Prace Geograficzne 94: 39-48.

Samołyk M., Tylkowski J., 2009. Morphology and lithology of the cliff shore of Petunia Bay in the Wordiekammen-Ebbaelva section, Central Spitsbergen. Quaestiones Geographicae 28A/2: 39-46.

Sendobry K., 1982. Geomorfologiczna działalność wód płynących na równinie Kaffiøyra (Spitsbergen). Wyprawy Polarne Uniwersytetu Śląskiego 1977-1980 1: 109-117.

Slaymaker O., 2011. Criteria to distinguish between periglacial, proglacial and paraglacial environments. Quaestiones Geographicae 30(1): 85-94.

http://dx.doi.org/10.2478/v10117-011-0008-y

Stankowski W., 1981. O morskim pochodzeniu mezorzeźby Lisbetdalen (SW Spitsbergen). VIII Sympozjum Polarne, Sosnowiec: 101-111.

Stankowski W. (ed.), 1989. Quaternary paleogeography and present-day processes in an area between Billefjorden and Austfjorden, central Spitsbergen. Polish Polar Research 10(3): 1-475.

Stankowski W., 1989. Interaction of marine glacial and lacustrime processes through morphogenesis of the region between Billefjorden and Austfjorden, central Spitsbergen. Polish Polar Research 10(3): 411-417.

Stankowski W., Kasprzak L., Kostrzewski A., Rygielski W., 1989. An outline of morphogenesis of the region between Hørbyedalen and Ebbadalen, Petuniabukta, Billefjorden, central Spitsbergen. Polish Polar Research 10(3): 267-276. 
Szczęsny R., 2004. Rzeźba i osady polodowcowe wybranych fragmentów południowego Spitsbergenu. In: A. Kostrzewski, M. Pulina, Z. Zwoliński (eds.), Glacjologia, geomorfologia i sedymentologia środowiska polarnego Spitsbergenu. Stowarzyszenie Geomorfologów Polskich, Sosnowiec-Poznań-Longyearbyen: 124-128.

Szczęsny R., Dzierżek J., Harasimiuk M., Nitychoruk J., Pękala K., Repelewska-Pękalowa J., 1989. Photogeological map of the Renardbreen, Scottbreen and Blomlibreen fiorefield (Wedel Jarlsberg Land, Spitsbergen, scale 1:10 000). Wydawnictwa Geologiczne, Warszawa.

Szczucińska A.M., 2011. Occurrence and temporal variations of groundwater outflows in the Petuniabukta region, Spitsbergen. Polish Polar Research 32(4): 361-374. http://dx.doi.org/10.2478/v10183-011-0023-7

Szczucińska A.M., Wasielewski H., 2013. Seasonal water temperature variability of springs from porous sediments in Gryżynka Valley, western Poland. Quaestiones Geographicae 32(3): 111-117. DOI 10.2478/quageo-2013-0019, ISSN 0137-477X

Szczuciński W., Zajączkowski M., 2012. Factors controlling downward fluxes of participate matter in glacier-contact and non-glacier contact setting in a subpolar fjord (Billefjorden, Svalbard). In: M.Z. Li, C.R. Sherwood, P.R. Hill (eds), Sediments, morphology and Sedimentary Processes on Continental Shelves. IAS Special Publication 44: 369-386.

Szczuciński W., Zajączkowski M., Scholten J., 2009. Sediment accumulation rates in subpolar fjords - impact of post-Little Ice Age glaciers retreat, Billefjorden, Svalbard. Estuarine, Coastal and Shelf Science 85(3): 345-356. http://dx.doi.org/10.1016/j.ecss.2009.08.021

Szuman I., Kasprzak L., 2010. Glacier ice structures influence on moraines developement (Hörbye glacier, Central Spitsbergen). Quaestiones Geographicae 29(1): 65-73. http://dx.doi.org/10.2478/v10117-010-0007-4

Szupryczyński J., 1963. Rzeźba strefy marginalnej i typy deglacjacji lodowców południowego Spitsbergenu. Prace Geograficzne 39 (+mapa)

Tomczyk A.M., Ewertowski M., 2010. Changes of Arctic landscape due to human impact, north part of Billefjorden area, Svalbard. Quaestiones Geographicae 29(A/1): 75-83

Werner A., 1993. Holocene moraine chronology, Spitsbergen, Svalbard: lichenometric evidence for multiple neoglacial advances in the Arctic. The Holocene 3: 128-137.

http://dx.doi.org/10.1177/095968369300300204
Wójcik C., 1981. Geological observations in the eastern part of the Forlandsundet Graben between Dahlbreen and Engelsbukta, Spitsbergen. Studia Geologica Polonica 73: 25-35.

Zagórski P., 2002. Rozwój rzeźby litoralnej północno-zachodniej części Ziemi Wedela Jarlsberga (Spitsbergen). Ph.D. thesis. Maria Curie-Skłodowska Univ., Lublin.

Zagórski P., Gajek G., Demczuk P., 2012. The influence of glacier systems of polar catchments on functioning of the coastal zone (Recherchefjorden, Svalbard). In: A.A. Beylich, Z. Zwoliński (eds.), Hydrogeomorphological processes in catchment geoecosystems. Zeitschrift für Geomorphologie 56, suppl. 1: 101-122.

Zagórski P., Harasimiuk M., Jezierski W., 2006. Ewolucja i współczesne wykształcenie wybrzeża NW części Ziemi Wedela Jarlsberga (Spitsbergen). In: J. Superson, P. Zagórski (eds.), Stan i zmiany środowiska przyrodniczego północno-zachodnej części Ziemi Wedela Jarlsberga (Spitsbergen) w warunkach zmian klimatu i antropopresji. UMCS, Lublin: 35-43.

Zagórski P., Pękala K., Repelewska-Pękalowa J., 2007. The role of the Renard Glacier in forming of shore zone. In: A. Kostrzewski, Z. Zwoliński (eds.), Geodiversity of polar landforms. Field trip guide, Bellsund. Landform Analysis 5: 160-162.

Zagórski P., Siwek K., Gluza A., 2008a. Zmiany zasiegu czoła i geometrii lodowca Renarda (Spitsbergen) na tle zmian klimatycznych XX wieku. Problemy Klimatologii Polarnej 18: 113-125.

Zagórski P., Siwek K., Gluza A., Bartoszewski S., 2008b. Changes in the extent and geometry of the Scott Glacier, Spitsbergen. Polish Polar Research 29, 2: 163-185.

Zwoliński Z., Kostrzewski A., Rachlewicz G., 2008. Environmental changes in the Arctic. In: S. Singh, L. Starkel, H.J. Syiemlieh (eds.), Environmental Changes and Geomorphic Hazards. Bookwell, Delhi: 23-36.

Zwoliński Z., Kostrzewski A., Pulina M. (eds.), 2013. Dawne i współczesne geoekosystemy Spitsbergenu: polskie badania geomorfologiczne / Ancient and modern geoecosystems of Spitsbergen: polish geomorphological research. Association of Polish Geomorphologists, Bogucki Wydawnictwo Naukowe, Poznań: 456 pp.

Zwoliński Z., Rachlewicz G., Mazurek M., Paluszkiewicz Re., 2007. The geoecological model for small tundra lakes, Spitsbergen. Landform Analysis 5: 113-118.

Zwoliński Z., Mazurek M., Paluszkiewicz R., Rachlewicz G., 2008. The matter fluxes in the geoecosystem of small tundra lakes, Petuniabukta coast, Billefjorden, Central Spitsbergen. Zeitschrift für Geomorphologie 52(1): 79-101.

http://dx.doi.org/10.1127/0372-8854/2008/0052S1-0079 